\title{
INTANGIBLE PROPERTY UNDER THE FEDERAL MAIL FRAUD STATUTE AND THE TAKINGS CLAUSE: A CASE STUDY
}

\author{
Michael J. HOSTETLER
}

At first blush, the reader might wonder what the federal mail fraud statute ${ }^{1}$ (or, more generally, federal criminal law) and the Takings Clause ${ }^{2}$ have in common. Surprisingly, perhaps, the most notable commonality is that many court decisions have hinged on how the court viewed property. Of course, in one regime, a taking of property can land one in jail, whereas in the other, a taking of property can result in compensation from the government. I believe such different results, hinging on the same concept, offer sufficient grist to justify this investigation.

At the broadest level, this Note asks whether the concept of property has remained unified or has become fractured upon exposure to the judicial system. ${ }^{3}$ When deciding a case, courts have

Copyright $\odot 2000$ by Michael J. Hostetler.

1. 18 U.S.C. $\$ 1341$ (1994):

Whoever, having devised or intending to devise any scheme or artifice to defraud, or for obtaining money or property ... places in any post office or authorized depository for mail matter, any matter or thing whatever to be sent or delivered by the Postal Service ... shall be fined under this title or imprisoned not more than five years, or both.

What I discuss about mail fraud will also apply to 18 U.S.C. § 1343 (1994), the statute prohibiting wire fraud. The only major difference between the two federal fraud statutes is the jurisdictional element (use of mails versus use of interstate wires); the property definitions are interchangeable. See, e.g., United States v. Brumley, 59 F.3d 517, 520 n.4 (5th Cir. 1995) ("The mail fraud ... and wire fraud ... statutes are nearly identical ...."); United States v. Castillo, 829 F.2d 1194, 1198 (1st Cir. 1987) ("The language of the (newer) wire fraud statute . . . tracks that of the (older) mail fraud statute... The requisite elements of the crimes... are identical."); United States v. Lemire, 720 F.2d 1327, 1334-35 n.6 (D.C. Cir. 1983) ("The requisite elements ... under the ... [statutes] ... are identical. Thus, cases construing mail fraud apply to the wire fraud statute as well.").

2. U.S. CONST. amend. V ("[N]or shall private property be taken for public use, without just compensation.").

3. In many ways, this Note is a study in comparative law. Most comparative law studies examine how different legal systems approach a problem. Thus, one might compare eminent domain policies in different countries. These studies allow one to appreciate better the unique 
the opportunity to apply the selective pressures of public policy to interpret and shape legal principles. The more malleable the principle, the more likely that different camps will form, which in turn creates the potential for the divergent evolution of the original principle. ${ }^{4}$ How does this scenario play out with a principle as nebulous as property? ${ }^{5}$ Essentially, there are two theoretical positions, which I will call the "pragmatist's universe" and the "idealist's universe."

In the pragmatist's universe, the perceived differences in policy behind each statute lead to two different visions of property. Thus, viewed through the lens of crime prevention, a broad definition of property is needed to uphold the convictions of those who creatively invent new types of wrongs; on the other hand, viewed through the lens of fiscal conservatism, a narrow definition of property is needed to hamper a takings claimant's case and give the government more flexibility to initiate projects inexpensively. Exposed to these different selective pressures, one would expect the meaning of property in criminal law is to evolve into a different form than in takings law.

In the idealist's universe, property generally has the same form in both criminal law and takings law because overarching principles,

features of a particular legal system and also, when applied historically, to understand what forces have caused a particular legal system to evolve in the way it has. A related approach, which this Note adopts, and which has not received as much attention, is to ask whether core legal concepts evolve differentially within different branches of the same legal system. One might imagine, for example, that when a legal system is relatively small and simple, most practitioners would be accomplished in several areas of law, and, as a result, developments in one area of law are likely to be consistent with the precedents in other areas of law. However, as the legal system becomes larger and more complex, the need for a practitioner to specialize becomes greater; as a result, some of the original common terms may evolve into terms of art. But do the most basic legal concepts, such as property, undergo differential evolution in separate branches of law? Or, are these fundamental concepts so vital to the broader system of law that differential evolution is constrained by, for example, public policy? A full exposition of these issues is left for another day.

4. For other applications of the concepts of Darwinian evolution to law, see generally JOHN H. BECKSTROM, EVOLUTIONARY JURISPRUdENCE: PROSPECTS AND LIMITATIONS ON THE Use of Modern Darwinism Throughout the Legal Process (1989); Raymond R. Coletta, The Measuring Stick of Regulatory Takings: A Biological and Cultural Analysis, 1 U. PA. J. Const. L. 20 (1998); and Owen D. Jones, Law and Evolutionary Biology: Obstacles and Opportunities, 10 J. CONTEMP. HEALTH L. \& POL'Y 265 (1994).

5. As will be shown, property can mean everything from land to the right to exclude another from land; from an automobile to the right to earn money from leasing the automobile; from a patent to secret information; from money to the right to control how money is spent. See infra Part II (discussing how the law has viewed property through the lenses of the mail fraud statute and the Takings Clause). 
such as basic fairness and preservation of a legal system's legitimacy, ensure that concepts of property do not differentially evolve. The idealist might argue that if the government is willing to say that something is property in order to send a person to prison, then it should be willing to pay compensation if the government itself takes the same property. This quid pro quo constrains the opposing policy forces in the pragmatist's universe from creating multiple forms of property.

But which viewpoint - the pragmatist's or the idealist's-emerges triumphant? To study this question, I have selected as my laboratory judicial interpretations of intangible property. Why intangible property? First, the question of what is property, especially for tangible objects and the rights that inhere within these objects, is relatively noncontroversial, and, as such, would make for a less interesting discussion. Second, differentiating intangible property from other intangible interests tests the limits of how we view property. Finally, in our information age, the intangible often has a value commensurate with the tangible, yet few articles have considered the judicial boundary between intangible interests and intangible property. ${ }^{6}$

After analyzing a broad range of intangible property interests, I find that, although the real world is more complex than either model, certain patterns do emerge. Thus, some types of intangible property are treated similarly under both the mail fraud statute and the Takings Clause, while a few are treated differently. Much more interesting, however (because of possible precedential value), are those intangible property interests that have only been analyzed in the light of one of these two areas of case law.

6. Although the view that intangible interests should be considered property has been around since the founding of the republic, see James Madison, Essay on "Property," NAT'L GAZETTE, Mar. 29, 1792, reprinted in THE Mind OF THE FOunder: SOURCES OF THE Political Thought of JAMES MAdison 186 (M. Meyers rev. ed. 1981) ("As we have a right to our property, so we have property in our rights."), few modern articles have revived this approach. See, e.g., John O. McGinnis, The Once and Future Property-Based Vision of the First Amendment, 63 U. CHI. L. REV. 49, 56 (1996) (arguing that Madison drafted the First Amendment in order to protect a citizen's "property right in their ideas and opinions"); Laura S. Underkuffler, On Property: An Essay, 100 YALE L.J. 127, 128-29 (1990):

During the American Founding Era, property included not only external objects and people's relationships to them, but also all of those human rights, liberties, powers, and immunities that are important for human well-being, including: freedom of expression, freedom of conscience, freedom from bodily harm, and free and equal opportunities to use personal faculties. 
Having described the world as it is, I then turn to describing the world as it should be. I adopt the philosophy presented by the idealist above and argue for a consistent vision of property. Thus, understandings of property in one body of case law should have precedential or referential value for the other area of case law. Consistency is needed to limit the executive branch's ability to prosecute overly broad statutes and to provide legitimacy to the government's eminent domain policies.

In Part I of this Note, I will present a brief introduction to the mail and wire fraud statutes and to the Takings Clause; in particular, I will illustrate the importance of property definitions to both areas of law. Part II analyzes a broad range of intangible interests and provides the testing ground for deciding whether courts have stretched the definition of property to the same extent in mail fraud prosecutions and in takings claims. This part is divided into three sections: convergent, divergent, and cutting-edge. The first two sections, respectively, describe types of property that courts have viewed either as substantially similar or substantially different in both areas of law. The third section discusses property interests that have been analyzed only in the light of either the mail fraud statute or the Takings Clause. In Part III, I will argue that, as a matter of legitimacy, and in order to provide adequate constraints on prosecutorial discretion, the meaning of property under federal criminal law (and, in particular, the mail and wire fraud statutes) should be precedent for the meaning of property in takings case law (and vice versa). Part IV concludes this Note by suggesting guidelines for courts to use when confronted with two of the cutting edge forms of intangible property: licenses and information necessary for a business decision.

\section{INTRODUCTION TO PROPERTY IN FEDERAL LAW}

\section{A. Property and Mail and Wire Fraud}

The federal mail fraud statute, enacted in 1872, was designed as a general "proscription against using the mails to initiate correspondence in furtherance of 'any scheme or artifice to defraud." "In 1909, Congress explicitly extended the reach of the statute to the protection of property rights by adding the words "or

7. McNally v. United States, 483 U.S. 350, 356 (1987) (quoting Act of June 8, 1872, ch. $335, \S 301,17$ Stat. $323(1872))$. 
for obtaining money or property by means of false or fraudulent pretenses, representations, or promises." $"$

Although other federal criminal statutes rely on definitions of property, ${ }^{9}$ mail fraud case law represents one of the most ambitious

8. Act of Mar. 4, 1909, ch. 321, § 215, 35 Stat. 1130 (1909) (codified at 18 U.S.C. $\S 1341$ ); see also McNally, 483 U.S. at 357-58 (tracing the evolution of the language of the mail fraud statute).

9. For example, the Hobbs Act, 18 U.S.C. $§ 1951(b)(2)$ (1994), defines extortion as "the obtaining of property from another, with his consent, induced by wrongful use of actual or threatened force, violence, or fear, or under color of official right." Id. Inclusion of the word "property" within the statute has led to attempts by prosecutors to extend the meaning of property to include intangible property rights. See Alexander M. Parker, Note, Stretching RICO to the Limit and Beyond, 45 DUKE L.J. 819, 826-27 (1996). For example, courts have found that the Hobbs Act protects such intangible property rights "as the right to hire employees and to solicit customer accounts," $i d$. at 826 , and the right to continue to operate one's business, see id. at 827 \& n.45; Feminist Women's Health Ctr. v. Roberts, No. C86-161Z, 1989 WL 56017, at *7 (W.D. Wash. May 5, 1989) (permitting Hobbs Act to apply to anti-abortion activists), and the right of union members to democratic participation within the union, see Parker, supra, at 827.

In addition, many statutes use the term "thing of value." Courts have generally had no difficulty in extending that term to intangible goods. For example, a court has interpreted "thing of value" in 18 U.S.C. $\$ 641$ to include information about DEA informants. See United States v. Girard, 601 F.2d 69, 70-71 (2d Cir. 1979); see also NORMAN ABRAMS \& SARA SUn BEALE, FEDERAL CRIMINAL LAW 228-29 (2d ed. 1993) ("The phrase 'thing of value' . . has generally been given a broad interpretation... encompassing various intangibles."); Peter J.G. Toren, The Prosecution of Trade Secrets Thefts Under Federal Law, 22 PePP. L. REV. 59, 93 (1994) (reviewing case law establishing "information as property under 18 U.S.C. § 641"). Essentially, the phrase "thing of value" has become a term of art found in many statutes. See Girard, 601 F.2d at 71. These cases are relevant for a discussion of the term "property." Courts have often relied on case law interpreting property to give meaning to the term "thing of value," and thus, for the purposes of this Note, "thing of value" and "property" are interchangeable. See, e.g., United States v. Mullins, 992 F.2d 1472, 1477 (9th Cir. 1993) (holding that frequent flyer mile accounts were "things of value"). This phrase also appears in judicial interpretations of the meaning of the phrase "to defraud." See, e.g., Hammerschmidt v. United States, 265 U.S. 182, 188 (1924) ("[T]he words 'to defraud' . . . have been given a wide meaning. . . . to wrong[] one in his property rights by dishonest methods or schemes.").

The National Stolen Property Act, which includes 18 U.S.C. § 2314 (1994) (prohibiting the transport of stolen property) and 18 U.S.C. $\S 2315$ (outlawing receipt or sale stolen property), defines property as "goods, wares, [and] merchandise." Notably, most courts have required that the intangible be converted into something tangible in order to fall under the ambit of these statutes. See, e.g., United States v. Brown, 925 F.2d 1301, 1308-09 (10th Cir. 1991) (dismissing an indictment based on the interstate electronic transfer of a computer file); United States v. Greenwald, 479 F.2d 320, 322 (6th Cir. 1973) (finding original documents detailing fire retardant formulations to be goods); United States v. Bottone, 365 F.2d 389, 393 (2d Cir. 1966) (stating that copies of papers detailing secret manufacturing processes are "goods" in the same way that original papers would be); United States v. Seagraves, 265 F.2d 876, 880 (3d Cir. 1959) (holding that geophysical maps are subjects of commerce insofar as they are sold separately). But see United States v. Riggs, 739 F. Supp. 414, 420-21 (N.D. Ill. 1990) (construing the language of the Act to encompass electronic transfer of computer files). The Supreme Court appears to agree with the majority of courts. See Dowling v. United States, 473 U.S. 207, 216 (1985) (asserting, in dicta, that section 2314 requires some sort of physicality of the stolen item). 
descriptions of property in all of case law. ${ }^{10}$ One reason for the availability of this broad analysis is the amazing flexibility of the statute. Besides a deprivation of a property interest, ${ }^{11}$ prosecutors need only prove an intent to defraud and the use of the mail as part of the crime. The ease of proving these three elements led Chief Justice Burger to comment:

Section 1341 of Title 18 U.S.C. has traditionally been used against fraudulent activity as a first line of defense. When a "new" fraud develops - as constantly happens - the mail fraud statute becomes a stopgap device to deal on a temporary basis with the new phenomenon, until particularized legislation can be developed and passed to deal directly with the evil. ${ }^{12}$

Perhaps the tangible sound of the phrase "goods, wares and merchandise" has been influential in leading courts to require a tangible form of property.

Federal drug laws that permit the state to seek forfeiture of a defendant's property that has been used to facilitate a drug crime can also apply to intangible property. See 21 U.S.C. $\S$ 853(a)(2) (1994). For example, a court recently used state law to hold that a medical license is a property right and thus forfeitable. See United States v. Dicter, 198 F.3d 1284, 1290 (11th Cir. 1999).

Interestingly, the Racketeer Influenced and Corrupt Organization Act (RICO), 18 U.S.C. $§ 1962$ (1994), which uses the federal mail and wire fraud statutes and the Hobbs Act as predicate offenses, has been held by most courts to require a harm to a tangible property interest. See, e.g., Price v. Pinnacle Brands, Inc., 138 F.3d 602, 607 (5th Cir. 1998) (stating that expectancy interests are not sufficient to establish RICO standing); Oscar v. University Students Coop. Ass'n, 965 F.2d 783, 785 (9th Cir. 1992) (requiring tangible financial loss for an injury to be actionable under RICO).

10. Furthermore, "[t]he mail fraud statute bears the distinction of being one of the oldest federal criminal provisions in continuous use." Gregory Howard Williams, Good Government by Prosecutorial Decree: The Use and Abuse of Mail Fraud, 32 ARIZ. L. REV. 137, 137 (1990). Enacted in 1872, see id., the mail fraud statute has a tremendous body of precedent and case law from which to draw. Recent statistics from the Department of Justice show that in 1997, 5031 mail or wire fraud investigations were initiated. See Federal Justice Statistics Resource Center, at http://fjsrc.urban.org (statistic calculated out of database available at this website) (last modified Mar. 20, 2000) (on file with the Duke Law Journal).

11. Throughout this Note, I will assume that the non-property elements of the mail and wire fraud statutes have been satisfied and that the controversy concerns whether the defendant tried to take property from the victim.

12. See United States v. Maze, 414 U.S. 395, $405-06$ (1974) (Burger, C.J., dissenting); see also Gerald E. Lynch, Our Administrative System of Criminal Justice, 66 FORDHAM L. REV. 2117, 2137 (1998) ("Mail fraud, money laundering, and a host of strict liability regulatory offenses are only the most notorious examples of statutes that are ill-defined, overbroad, or insufficiently concerned with culpability."); Jed S. Rakoff, The Federal Mail Fraud Statute (pt. 1), 18 DUQ. L. REV. 771, 771 (1980) (noting that prosecutors refer to mail fraud as "our Stradivarius, our Colt 45, our Louisville Slugger, our Cuisinart"); Ralph K. Winter, Paying Lawyers, Empowering Prosecutors, and Protecting Managers: Raising the Cost of Capital in America, 42 DUKE L.J. 945, 954 (1993) (referring to mail fraud as a prosecutor's "hydrogen bombs on stealth aircraft"). 
Judges have long appreciated the power and flexibility of the term "property." Some seemed awed by the ability of the term to send new types of cheats to federal prison; others were bothered by the fact that "[a] limitless reading of the mail fraud statute could result in a kind of federal criminal common law, that is, a situation where a person could be convicted of a crime against the United States despite the conduct not violating an express statutory provision." ${ }^{13}$ Still others feared that the ability of prosecutors to mold the mail fraud statute to fit the crime allowed prosecutions based on

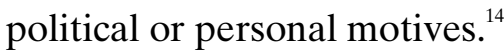

These concerns took on new meaning when the Supreme Court held in McNally v. United States ${ }^{15}$ that the mail fraud statute was limited to property interests. ${ }^{16}$ Because McNally was made retroactive, numerous defendants who had been convicted of mail fraud appealed to courts to vacate their convictions. ${ }^{17}$ Although many were successful, judges more often found creative ways to find property interests that permitted the convictions to stand. In addition, prosecutors were forced to develop strategies for detecting property interests in the post-McNally world. However, it was not long before courts began defining a wide range of intangible interests as property. ${ }^{18}$ As a result, mail fraud case law has become an ideal arena in which to test new theories of property.

13. United States v. Brown, 79 F.3d 1550, 1556-57 (11th Cir. 1996); see also United States v. Margiotta, 688 F.2d 108, 139-44 (2d Cir. 1982) (Winter, J., dissenting) (criticizing the majority for creating a catch-all political crime through its interpretation of the mail fraud statute).

14. See, e.g., Peter J. Henning, Maybe It Should Just Be Called Federal Fraud: The Changing Nature of the Mail Fraud Statute, 36 B.C. L. REV. 435, 437-38 (1995) (noting both the malleability and the broad applicability of the mail fraud statute); Geraldine Szott Moohr, Mail Fraud and the Intangible Rights Doctrine: Someone to Watch over Us, 31 HARV. J. ON LEGIS. 153, 155-56 (1994) (exploring the potential for politically motivated prosecution); Williams, supra note 10, at 143-44 (comparing the investigation rate for mail fraud $(1.3 \%$ of all complaints) with a claimed norm for investigations of crimes (40-60\% of all complaints) and concluding that prosecutorial discretion in mail and wire fraud cases is dangerously broad and a potential area in which "personal and political judgments ... influence charging decisions").

15. 483 U.S. 350 (1987).

16. See id. at 356 .

17. See, e.g., Lomelo v. United States, 891 F.2d 1512, 1515 n.8 (11th Cir. 1990) (listing circuits that have held that "McNally applies retroactively to convictions that became final before McNally was handed down").

18. See, e.g., United States v. Bucuvalas, 970 F.2d 937, $942-45$ (1st Cir. 1992) (describing post-McNally cases that have grappled with whether licenses constitute government property). 


\section{B. Property and the Takings Clause}

Governments have used the principle of eminent domain since the time of ancient Rome to force the transfer of property from an owner to itself. ${ }^{19}$ However, the idea of actually compensating the owner is a relatively new concept-one that has been embodied in a fundamental principle of the Constitution of the United States. ${ }^{20}$ And yet, the situation is not quite that simple. In order to actually receive the compensation, the bereaved owner generally has to bring a claim against the government and prove that something was actually taken, that the thing taken was property, that the thing taken was for a public use, and that the owner has not been adequately compensated.

The determination of a property interest is thus one of the key factors in any takings claim. The Supreme Court made this task more abstract (and perhaps simpler for the claimant) by extending the meaning of property to include not only the actual tangible object but also "the group of rights inhering in the citizen's relation to the physical thing. ${ }^{21}$ These rights have been coined sticks in our bundle of rights, and include the "right to possess, use and dispose of," 22 as

19. See JesSe DuKEMINIER \& JAMES E. KRIER, Property 1102 (4th ed. 1998).

20. Property is protected under the Fifth Amendment by both the Takings Clause, see U.S. CONST. amend. V ("[N]or shall private property be taken for public use, without just compensation."), and the Due Process Clause, see U.S. CONST. amend. V ("[N]or shall [any person] be deprived of life, liberty, or property, without due process of law ..."). Despite their proximity in the Constitution, courts seem to be more willing to find a due process property right than a Takings Clause property right. See Rocky Mountain Materials \& Asphalt, Inc. v. Board of County Comm'rs, 972 F.2d 309, 311 (10th Cir. 1992) (noting that "[t]here are many intangible [property] rights that merit the protection of procedural due process although their infringement falls short of an exercise of the power of eminent domain" (quoting Landmark Land Co. v. Buchanan, 874 F.2d 717, 723 (10th Cir. 1989))); Nasierowski Bros. Inv. Co. v. City of Sterling Heights, 949 F.2d 890, 894 (6th Cir. 1991) (citing Landmark for the same proposition); Mitchell Arms, Inc. v. United States, 26 Cl. Ct. 1, 6 (1992) (holding that a property interest under the Due Process Clause is not the same as a property interest under the Takings Clause). A quick examination of the case law shows that courts have held a broad range of intangible interests to be property (or possibly a liberty) for due process purposes, including the right to redress discrimination in court, see Logan v. Zimmerman Brush Co., 455 U.S. 422, 43031 (1982), the right to a high school education, see Goss v. Lopez, 419 U.S. 565, 573-74 (1975), and the right to state and federal welfare benefits, see Goldberg v. Kelly, 397 U.S. 254, 261-63 (1970). As this Note will demonstrate, however, courts are more cautious about doing the same under a takings analysis. In some ways, this discrepancy is rational because providing a minimal amount of procedural protection is substantially less expensive to the government than having to pay compensation. For reasons explained below, I prefer to have the government make the more difficult choice and equate Takings Clause property with criminally convictable property.

21. United States v. General Motors, 323 U.S. 373, 378 (1945).

22. Id. 
well as the "right to exclude." 23 As such, cases involving tangible objects seldom revolve around whether a property right is at stake. ${ }^{24}$

Nevertheless, scholarship on the meaning of property in light of the Takings Clause has become a veritable cottage industry. ${ }^{25}$ Although some try to make sense out of the case law, ${ }^{26}$ the majority appear concerned with finding ways to limit (or expand) the definition of property in order to ease (or hinder) the way for more aggressive environmental legislation, wealth distribution, ${ }^{27}$ or the promotion of some other special interest. ${ }^{28}$ This Note does not attempt to make sense out of this scholarly debate; it merely points out that definitions of property continue to have great importance in takings jurisprudence. Interestingly, however, few articles have discussed whether interests unconnected to tangible property deserve to be labeled as property for purposes of the Takings Clause. Given the increasing importance of intangible interests in our information age, this gap needs to be filled.

23. Loretto v. Teleprompter Manhattan CATV Corp., 458 U.S. 419, 433 (1982) (quoting Kaiser Aetna v. United States, 444 U.S. 164, 176 (1979)).

24. In these cases, the more general problems that courts face are whether the property was taken and whether compensation must be given.

25. See, e.g., Jeanne L. Schroeder, Never Jam Today: On the Impossibility of Takings Jurisprudence, 84 GEO. L.J. 1531, 1531 (1996) ("[H]undreds of recent articles attempt[] to reconcile, critique, or condemn Supreme Court takings jurisprudence or to justify, reinterpret, or re-imagine the underlying theory of property.").

26. See, e.g., D. Benjamin Barros, Note, Defining "Property" in the Just Compensation Clause, 63 FordHAM L. REV. 1853, 1868 (1995) ("Defining 'property' in the Just Compensation Clause is necessary to avoid the confusion that has characterized modern takings law.").

27. See, e.g., Thomas W. Merrill, Compensation and the Interconnectedness of Property, 25 ECOLOGY L.Q. 327, 344-49 (1998). Professor Merrill, who has commented on the property theories of many scholars, describes two general property camps. One is represented by Bruce Ackerman, who advocates the "Ordinary Observer's" concept of property, "i.e. property as specific assets or "things." Id. at 347. The other camp advocates a concept of property as a bundle of rights. Surprisingly, this camp is composed of polar opposites on the political spectrum. For example, Richard Epstein advocates a broad concept of property as a means of limiting government intervention into private life. On the other hand, Joseph Sax and Frank Michelman, while agreeing with the broader conception of property, argue that the state's police powers permit the regulation of property and that our participation in society is an implicit acceptance that the police powers can be used to diminish the value of our property if used for the common good. Professor Michelman sees the common good as the redistribution of wealth to the poor, whereas Professor Sax's goal is to protect the environment. See id.; see also Leif Wenar, The Concept of Property and the Takings Clause, 97 COLUM. L. REV. 1923, 1931-35 (1997) (dividing up property philosophers into similar camps).

28. See, e.g., Susan E. Looper-Friedman, "Keep Your Laws Off My Body": Abortion Regulation and the Takings Clause, 29 NEW ENG. L. REV. 253 (1995) (advocating a property right in one's body and arguing that abortion laws are uncompensated takings of this property right). 


\section{THE LABORATORY OF INTANGIBLE PROPERTY}

\section{A. Convergent Evolution}

This section describes types of property that courts have viewed in substantially the same manner in both mail fraud prosecutions and takings claims. I use the term "convergent evolution" to describe this phenomenon because the concept of property has evolved similarly in each area of law, even though one area has had little apparent influence on the other. For example, few mail fraud cases have looked at a takings claim case (and vice versa) in order to reach a conclusion about the meaning of property. Thus, despite widely different fact patterns, policy rationales, and other selective pressures, property in each regime would still be recognizable in the other regime.

1. Trade Secrets. Viewed from our vantage point in the information age, the idea that a trade secret ${ }^{29}$ is a form of property would not likely raise any eyebrows. Trade secrets, because of their competitive value, are typically considered a major asset in any company's intellectual property estate.$^{30}$ In addition, a trade secret is not confined to its originator but can be bought and sold. ${ }^{31}$ As a result, it is unsurprising that many states, following the Restatement of Torts, recognize trade secrets to be property. ${ }^{32}$

However, a trade secret is an unusually fragile type of property. Once the owner loses control of its disposition, the value of the trade secret is shattered. Thus, courts were relatively quick to recognize

29. The Restatement of Torts offers a typical definition of a trade secret:

[A]ny formula, pattern, device or compilation of information which is used in one's business, and which gives him an opportunity to obtain an advantage over competitors who do not know or use it. It may be a formula for a chemical compound, a process of manufacturing, treating or preserving materials, a pattern for a machine or other device, or a list of customers.

RESTATEMENT (FIRST) OF TORTS $\$ 757 \mathrm{cmt} . \mathrm{b}$ (1939).

30. One of the most famous, and certainly one of the most valuable, of all trade secrets is the formula for Coca-Cola, protected for over 100 years. See Coca-Cola Bottling Co. v. CocaCola Co., 107 F.R.D. 288, 294 (D. Del. 1985) (granting the plaintiff's motion to compel production of the defendant's trade secret so that the plaintiffs might support their claims and respond to the argument that Coca-Cola and Diet Coke were two different products).

31. See, e.g., S.J. Soltysinskí, Are Trade Secrets Property?, 17 INT'L REV. INDUS. Prop. \& COPYRIGHT L. 331, 331 (1986) ("Trade secrets, know-how and other intangibles covering technical and commercial knowledge... represent enormous economic values, and are the fastest growing major commodity in many countries.”).

32. See RESTATEMENT (FIrST) OF TORTS $\S 757 \mathrm{cmt}$ b (1939). 
that criminal liability may lie in actions that cause such a loss. ${ }^{33}$ In fact, trade secrets were probably the first type of intangible property with which courts were willing to permit a mail fraud conviction. In a classic case, Procter \& Gamble was indicted under the mail fraud statute for trying to convince a rival's employees to leak out secret formulas for soap products. ${ }^{34}$ In overruling a demurrer for the indictment, the district court recognized the inherent value of the secret formula, the dependence of this valuation upon continued nondisclosure, and the economic harm that would be suffered if a competitor acquired one's trade secrets. ${ }^{35}$ Subsequent courts have relied upon similar reasoning to sustain indictments or uphold convictions under the mail and wire fraud statutes against those who, using fraud, acquired secret formulas, facts, processes, and figures from a company.

Takings case law appears to have adopted a similar view of trade secrets. For example, in Ruckelshaus v. Monsanto, ${ }^{37}$ the Supreme Court decided that a trade secret was property. ${ }^{38}$ At issue was a provision in the Federal Insecticide, Fungicide, and Rodenticide Act

33. See, e.g., United States v. Procter \& Gamble Co., 47 F. Supp. 676, 678 (D. Mass. 1942) (overruling Procter \& Gamble's demurrer to a mail fraud indictment arising from an alleged scheme to obtain trade secrets by bribing a competitor's employees).

34. See id.

35. See id. at 678 .

36. See, e.g., Formax, Inc. v. Hostert, 841 F.2d 388, 390 (Fed. Cir. 1988) (reversing a district court's dismissal of an employer's Racketeer Influenced and Corrupt Organizations Act (RICO) count against a former employee who allegedly stole drawings claimed as trade secrets and infringed the employer's patent); United States v. Kent, 608 F.2d 542, 544 (5th Cir. 1979) (holding that an indictment for mail fraud was sufficient, since the alleged scheme to defraud an oil company was dependent on mailed documents including confidential geological data); United States v. Seidlitz, 589 F.2d 152, 160 (4th Cir. 1978) (affirming a wire fraud conviction resulting from transmitting telephone calls as part of a scheme to defraud a company of property consisting of information from a computer system); Abbott v. United States, 239 F.2d 310, 314 (5th Cir. 1956) (upholding a conviction for mail fraud resulting from the defendant mailing payment to a person procuring copies of an oil company's geophysical maps); United States v. Wang, 898 F. Supp. 758, 760 (D. Colo. 1995) (denying a motion to dismiss an indictment for wire fraud resulting from the alleged transmission of copyrighted computer files containing confidential source code); United States v. Riggs, 739 F. Supp. 414, 418-19 (N.D. Ill. 1990) (holding that an indictment for wire fraud sufficiently set forth the existence of a scheme to "defraud Bell South out of property - the confidential information contained in [its enhanced 911 system]"); United States v. Caparros, No. 85 Cr. 990 (JFK), 1987 WL 26784, at *1-2 (S.D.N.Y. Nov. 24, 1987) (declining a motion to dismiss wire and mail fraud indictments resulting from an alleged scheme to defraud a chewing gum manufacturer out of pricing policies, promotional campaigns, product safety information, and new products).

37. 467 U.S. 986 (1984).

38. See id. at 1003-04. 
that allowed the EPA to consider data submitted by one registrant to support a subsequent applicant's efforts to register a similar chemical as long as the subsequent applicant offered to compensate the original provider of data. ${ }^{39}$ If neither party could agree on a price, either had the right to initiate binding arbitration subject to limited judicial review. If the original submitter refused to participate in the arbitration, the claim for compensation would be forfeited. ${ }^{40}$

Relying on a mixture of state law, ${ }^{41}$ congressional statements, ${ }^{42}$ and observations that trade secrets and tangible property share many characteristics, ${ }^{43}$ the Court had no difficulty holding that a trade secret was property. Furthermore, the Court noted that other types of intangible interests had already been held to be property for purposes of the Takings Clause. ${ }^{44}$ However, the Court limited the compensable interest to information that the EPA had expressly promised to treat as a trade secret. ${ }^{45}$ Surprisingly, a general protection, such as the Trade Secrets Act, which made criminal unauthorized disclosure of trade secrets by a government official, was insufficient to provide a reasonable expectation that submitted data was protected from disclosure. ${ }^{46}$ In essence, the Court held that a highly regulated industry should reasonably expect that data submitted to the government for one purpose will be used by the government for other purposes.

In both areas of law, courts recognize that trade secrets are property. Unauthorized disclosure of the latter can lead to either a conviction or a government taking.

\footnotetext{
39. See id. at 992.

40. See id. at $994-95$.

41. See id. at 1003-04. In this case, Missouri, the relevant state, recognized trade secrets as property, relying on the Restatement of Torts definition. See RESTATEMENT (FIRST) OF TORTS $\S 757 \mathrm{cmt}$. b (1939).

42. See Ruckelshaus, 467 U.S. at 1002 ("Congress reasoned that submitters of data are 'entitled' to 'compensation' because they 'have legal ownership of the data."' (quoting H.R. CONF. REP. No. 95-1560, at 29 (1978), reprinted in 1978 U.S.C.C.A.N. 1966, 2045)).

43. See id. (noting that trade secrets are assignable, can form the res of a trust, and can pass to a trustee in bankruptcy).

44. See id. at 1003. The Court noted that it had previously found materialman's liens, real estate liens, and valid contracts to be property. See id. (citations omitted).

45. See id. at 1010-12. The Court also relied on its long-held rule that "[t]he right to exclude others is generally 'one of the most essential sticks in the bundle of rights that are commonly characterized as property." Id. at 1011 (quoting Kaiser Aetna v. United States, 444 U.S. 164, $176(1979))$.

46. See id. at 1008 .
} 
2. Patents, Copyrights, and Trademarks. Although intangible, patents, copyrights and trademarks are clearly recognized forms of property. Moreover, federal laws specifically provide rights to owners of these types of intellectual property, ${ }^{47}$ such as the right to seek redress in federal court against alleged misappropriators. ${ }^{48}$ In general, however, criminal sanctions are not available under these statutory schemes.

Could mail or wire fraud be used to bring a conviction against a person who tried fraudulently to obtain a patent because the application was sent by mail or interstate courier to the USPTO? Despite the appeal of this scenario, no such case has arisen. However, private parties have periodically brought RICO charges ${ }^{49}$ against competitors where the predicate offenses were mail or wire fraud. ${ }^{50}$ For example, plaintiffs have claimed that a defendant "committed numerous acts of mail and/or wire fraud on the United States Patent and Trademark Office ('PTO') which resulted in approval of certain patent applications," and that the defendant "then sought money from [the plaintiff] and others by threatening them with litigation over these fraudulently obtained patents." ${ }^{51}$ The critical issue in these cases is whether the government has a property interest in unissued

47. Federal patent law allows one to prevent others from practicing the invention but does not grant an actual right to practice the invention; however, federal copyright law gives the copyright owner the "sole right to reproduce, distribute, perform, and display the protected work, as well as the right to prepare derivative works." Roberta Rosenthal Kwall, Governmental Use of Copyrighted Property: The Sovereign's Prerogative, 67 TEX. L. REV. 685, 686 (1989) (citing 17 U.S.C. § 102(a) (1982)). In both cases, information represents the situs of the property. However, the owner of a copyright has more sticks in her bundle of property rights (the right to use, transfer, and exclude) than does the patent owner (the right to transfer and exclude). For an interesting argument on the historical interpretation of information as property, and for the impact of the modern view that information is property on intellectual property law, see generally Pamela Samuelson, Information as Property: Do Ruckelshaus and Carpenter Signal a Changing Direction in Intellectual Property Law?, 38 CATH. U. L. REV. 365 (1989)

48. In regard to patent infringements suits, see 35 U.S.C. $§ \S 283-85$ (1994) (discussing injunctions, damages, and attorneys' fees, respectively).

49. See 18 U.S.C. § 1962 (1994) (defining RICO activities). A plaintiff must demonstrate that the defendant participated in a pattern of criminal activity, which can include mail and wire fraud. See id.; id. § 1961(1)(B).

50. See, e.g., Semiconductor Energy Lab. Co. v. Samsung Elec. Co., 4 F. Supp. 2d 473, 475 (E.D. Va. 1998) (finding no RICO cause of action in a patent case); Select Creations, Inc. v. Paliafito Am., Inc., 828 F. Supp. 1301, 1359 (E.D. Wis. 1992) (finding a RICO cause of action in a patent case); Michael Anthony Jewelers, Inc. v. Peacock Jewelry, Inc., 795 F. Supp. 639, 650 (S.D.N.Y. 1992) (dismissing RICO charges for failure to state a cause of action in a trademark case).

51. Semiconductor Energy Lab., 4 F. Supp. 2d at 475 (footnote omitted). 
patents or copyrights. Although all courts have acknowledged that the patent or copyright, once issued, is property in the hands of the inventor or the author, few courts have been willing so to characterize the government's interest.

In general, few takings cases have revolved around whether patents, copyrights, or trademarks are property. For example, although numerous courts have awarded a patent holder compensation under the principles of the Takings Clause, ${ }^{52}$ these cases never questioned whether the information in the patent was property. Few takings claims have involved other types of intellectual property, ${ }^{53}$ so one is left to wonder how courts might view such cases.

3. Other Business Assets or Contract Rights. Under the mail and wire fraud statutes, courts usually consider an intangible business asset or contract right to be property if the interest may be converted into money. ${ }^{54}$ These opportunities include a creditor's right to try to collect a debt from a debtor via a court action, ${ }^{55}$ the right of a

52. See Hughes Aircraft Co. v. United States, 86 F.3d 1566, 1571 (Fed. Cir. 1996) ("The government's unlicensed use of a patented invention is properly viewed as a taking of property under the Fifth Amendment...."); Standard Mfg. Co. v. United States, 42 Fed. Cl. 748, 757 (1999) ("Because recovery is based on eminent domain, the proper measure of compensation is "what the owner has lost, not what the taker has gained."” (quoting Leesona Corp. v. United States, 599 F.2d 958, 969 (Ct. Cl. 1979))).

53. For example, there are no reported cases in which a state or federal government tried to use its power of eminent domain to acquire rights to copyrighted material, although copyright owners have tried to use inverse condemnation proceedings. See Kwall, supra note 47, at 694 \& nn.36-37. The challenge was not whether the copyrighted material was property, but whether the government took the property. See id. However, takings claims may soon become the sole recourse for intellectual property owners against states who are using the intellectual property without the owner's permission. See Shubha Ghosh, Toward a Theory of Regulatory Takings for Intellectual Property: The Path Left Open After College Savings v. Florida Prepaid, 37 SAN DiEgo L. REV. 637, 639 (2000) (applying the Takings Clause to all types of intellectual property).

54. For example, frequent flyer miles that have not been claimed by passengers have value to airlines because the airlines save the value of a free ticket. See United States v. Mullins, 992 F.2d 1472, 1477 (9th Cir. 1993); United States v. Loney, 959 F.2d 1332, 1336 (5th Cir. 1992); United States v. Schreier, 908 F.2d 645, 647 (10th Cir. 1990).

55. See United States v. Adler, 186 F.3d 574, 576 (4th Cir. 1999) (noting that the plaintiff creditor "clearly had a property interest in the chose in action"); United States v. Mancuso, 42 F.3d 836, 845 (4th Cir. 1994) (holding that these rights "fall within the universe of property that will support" a conviction); United States v. Holzer, 840 F.2d 1343, 1348-49 (7th Cir. 1988) (noting in dicta that efforts to prevent another from re-obtaining wrongfully taken property could be construed as taking away the other person's right to a chose in action, which is a property right itself); United States v. Eisen, No. CR-90-00018, 1990 WL 164681, at *3 (E.D.N.Y. Oct. 19, 1990) (observing that a cause in action is the property of a creditor seeking funds from a debtor); United States v. Khashoggi, No. SSSS 87 CR.598(JFK), 1990 WL 31874, at 
government to bring an accused person into court in order to collect a fine ${ }^{56}$ or the right of a government to try to collect unpaid tax revenue. ${ }^{57}$ All of these cases involve the right of an entity to go to court. Note that these defendants were not accused of actually taking money because the victims' claims had not yet been tried in courtthe defendants' crimes lay in committing acts that decreased the victims' likelihood of obtaining a favorable verdict. Nevertheless, courts, relying on state law ${ }^{58}$ or the contractual value of a chose in action, ${ }^{59}$ have found these intangible interests to be property.

Similarly, courts have found that a property right exists sufficient to sustain a criminal conviction when the thing that is taken has been (or could be) bargained for in a contract. These include intangible contract rights that an employee bargains for with an employer, ${ }^{60}$ the intangible benefits that arise from purchasing an item from a charity, ${ }^{61}$

*13 (S.D.N.Y. Mar. 13, 1990) (noting that an adjudicable claim is property). But see United States v. Miller, 997 F.2d 1010, 1021-22 (2d Cir. 1993) (refusing to extend a property right to a chose in action to include an attempt to collect a debt).

56. See United States v. Sepulveda, 763 F. Supp. 352, 355 (N.D. Ill. 1991) (holding that a police officer who took bribes in exchange for dropping cases deprived the state of property in the form of the fines, which would have gone to the state if the accused had been found guilty); LeFevour v. United States, 748 F. Supp. 579, 583 (N.D. Ill. 1990) (holding that a judge who dismissed parking tickets in exchange for bribes deprived the city of a cause of action to get the fines); United States v. Manganiello, No. 87 CR 325, 1989 WL 91850, at*3 (N.D. Ill. Aug. 1, 1989) (holding that a police officer who took bribes in exchange for preventing prosecution of charges had designed the scheme to deprive the city of property to which it was entitled).

57. See United States v. Trapilo, 130 F.3d 547, 552 (2d Cir. 1997) (holding that a scheme to deprive a country of tax revenue is a scheme to deprive that country of property); United States v. Bucey, 876 F.2d 1297, 1310 (7th Cir. 1989) (deciding that uncollected federal income tax is the government's property); United States v. Doe, 867 F.2d 986, 989 (7th Cir. 1989) (holding that a county has a property right in uncollected tax revenue); United States v. Porcelli, 865 F.2d 1352, 1360 (2d Cir. 1989) (holding that unpaid taxes are intangible property protected by the mail and wire fraud statutes).

58. See Doe, 867 F.2d at 989; Eisen, 1990 WL 164681, at *3.

59. See Adler, 186 F.2d at 577 (noting that a chose in action is property because property is anything in which one has a "right that could be assigned, traded, bought, and otherwise disposed of").

60. See United States v. Rastelli, 870 F.2d 822, 830 (2d Cir. 1989) (deciding that the economic benefits that an employee obtains through collective bargaining, including "jobs, wages, seniority rights, and pension benefits" are the property of the employee); United States v. Boffa, 688 F.2d 919, 930 (3d Cir. 1982) (same).

61. See United States v. Hawkey, 148 F.3d 920, 924 (8th Cir. 1998) (holding that the receipt of concert proceeds by a charitable organization was part of the bargain). But see United States v. Regent Office Supply Co., 421 F.2d 1174, 1181 (2d Cir. 1970) (holding that a seller's false claims that office supplies were being sold to raise money for a family that had lost its breadwinner had not been shown to be part of the bargain). 
and a person's time ${ }^{62}$ or image. ${ }^{63}$ However, the mere expectation of a contract (business deal, ${ }^{64}$ market share ${ }^{65}$ or employment ${ }^{66}$ ) does not rise to the level of a property right.

In mail fraud cases, courts have even found that a business has a property right to conduct its business free from certain extremely competitive practices, such as harassment ${ }^{67}$ or unfair customer manipulation. ${ }^{68}$ Nevertheless, courts may refuse to prosecute those

62. See United States v. DeFusco, 930 F.2d 413, 415 (5th Cir. 1991) (holding that using fraud to waste someone's time is a cognizable deprivation of property); United States v. Condolon, 600 F.2d 7, 9 (4th Cir. 1979) (same).

63. See United States v. Cross, 928 F.2d 1030, 1043-44 (11th Cir. 1991) (holding that a person has a property right in her photographs and "the likenesses that emanate therefrom"); United States v. Diwan, 864 F.2d 715, 720 (11th Cir. 1989) (same).

64. Interestingly, while some courts have found that the company seeking bids has a property right in controlling the bidding process, see infra note 183 and accompanying text, courts have generally not found that the bidders have a property right in a fair bidding process. For example, in United States v. Henry, 29 F.3d 112 (3d Cir. 1994), the court agreed that a fair bidding process was valuable but "[a]t most, the condition is a promise to the bidding banks from those in charge of the process that they would not interfere with it. It is not a grant of a right of exclusion, which is an important aspect of traditional property." Id. at 115 . The dissent argued that the competing bidders would have had "a civil remedy against these defendants and Bank A for the tortious interference with prospective contractual relationships," and, as a result, a cognizable property right. Id. at 118 (Weis, J., dissenting). Similarly, in United States $v$. Berlin, 707 F. Supp. 832 (E.D. Va. 1989), the court felt it intuitively obvious that the "mere expectation of a contract" was not a cognizable property interest for companies competitively bidding for a contract. $I d$. at 835 . However, the Berlin court did agree that the opportunity to compete on a level playing field for a contract might be an intangible property right, based on an earlier Fourth Circuit case, United States v. Venneri, 736 F.2d 995 (4th Cir. 1984). See Berlin, 707 F. Supp. at 835. Nevertheless, the Berlin court overextended the Supreme Court's decision in McNally v. United States, 483 U.S. 350 (1987) (holding that the right to honest services was not a property right), in holding that mail and wire fraud were limited to tangible property rights. See infra Part II.C.1.

65. See Lancaster Community Hosp. v. Antelope Valley Hosp. Dist., 940 F.2d 397, 406 (9th Cir. 1991) (noting that a company's market share is not the property of the company); Pharmacare v. Caremark, 965 F. Supp. 1411, 1419 (D. Haw. 1996) (holding that a market share is not the property of a company).

66. See Roitman v. New York City Transit Auth., 704 F. Supp. 346, 349 (E.D.N.Y. 1989) (" $[\mathrm{T}] \mathrm{o}$ have a property interest in a benefit, a person must have more than an abstract need or desire for it. He must have more than a unilateral expectation of it. He must, instead, have a legitimate claim of entitlement to it." (quoting Board of Regents v. Roth, 408 U.S. 564, 577 (1972))).

67. See Feminist Women's Health Ctr. v. Roberts, No. C86-161Z, 1989 WL 56017, at *11 (W.D. Wash. May 5, 1989) (holding that under the mail fraud statute " [r]ights involving the conduct of business are property rights"” (quoting Northeast Women's Ctr., Inc. v. McMonagle, 868 F.2d 1342, 1350 (3d Cir. 1989))).

68. See Israel Travel Advisory Serv., Inc. v. Israel Identity Tours, Inc., 61 F.3d 1250, 1258 (7th Cir. 1995) (observing that lost business opportunities are property covered by 18 U.S.C. $\S$ 1341). 
who merely impair an entity's reputation, arguing that a reputation is not a property interest. ${ }^{69}$

In summary, courts desire to use federal criminal law to protect intangible business assets and contract rights, especially if precedent exists in state law, or if the intangible interest has been, or could be, exchanged for valuable consideration. The courts appear to balk, however, at sending someone to jail for practices that only hinder the fulfillment of expectations (or are, arguably, part of a "tough, but fair" free market).

As with the mail fraud statute, courts have usually considered an intangible interest to be property in a takings claim if the interest has obvious monetary value, either because the interest could be converted readily into money or tangible property, ${ }^{70}$ because someone paid money to acquire the interest, ${ }^{71}$ or because the interest was a valuable business asset. ${ }^{72}$ In addition, consonant with the mail and wire fraud understanding of property, courts typically have recognized contract rights as a valuable form of property under the

69. See, e.g., Roitman, 704 F. Supp. at 349 (holding that the plaintiff did not have a property interest in his "reputation, good name, honor, and integrity").

70. See, e.g., Armstrong v. United States, 364 U.S. 40, 44, 46 (1960) (holding that materialman's liens can constitute a property interest); Louisville Joint Stock Land Bank v. Radford, 295 U.S. 555, 596-602 (1935) (holding that real estate liens can constitute a property interest).

71. See Swan Lake Hunting Club v. United States, 381 F.2d 238, 240 (5th Cir. 1967) (upholding the condemnation of the hunting rights of a duck-hunting club and thus implicitly acknowledging that the right to hunt on private land is a form of intangible property).

72. See Kimball Laundry Co. v. United States, 338 U.S. 1, 10-11 (1949) (declaring that laundry routes were an asset with a value ascertainable by the market). In addition, Kimball Laundry held that the going-concern value of a business is property under the Takings Clause. See id. at 11 (citing three Supreme Court cases for support). Unfortunately, the Court seriously muddied the waters in Almota Farmers Elevator \& Warehouse Co. v. United States, 409 U.S. 470 (1973), which held that a business can be compensated for certain expectation interests, while at the same time stating that such expectation interests were not property under the Takings Clause. See id. at 475; see also id. at 481 (Rehnquist, C.J., dissenting) (noting, with irony, that although the majority did not find that petitioner's expectation interest was property, the Court nevertheless concocted a means to compensate petitioner for that interest anyway). For a critique of these cases and an analysis of the situation in the states, see Lynda J. Oswald, Goodwill and Going-Concern Value: Emerging Factors in the Just Compensation Equation, 32 B.C. L. REV. 283, 317-19 (1991). To my mind, courts are just confusing themselves when arguing whether or not intangible business assets are property. Clearly, on the market these intangible assets add value to a business, and in tort lawsuits, can even be valued. See, e.g., Carrey v. Boyes Hot Springs Resort, Inc., 54 Cal. Rptr. 199, 202 (Ct. App. 1966) (holding that the trial court should have separately valued loss of profit and loss of goodwill). The real issue is whether the government action has taken the property. Thus, unless the government actually takes the business (as opposed to the land under the business), the intangible business assets arguably remain with the owner and can be transferred to wherever the owner next sets up shop. 
Takings Clause. ${ }^{73}$ In general, the courts recognize that if someone is willing to bargain for and exchange some form of consideration for an intangible right, then that intangible interest is property.

For example, the Supreme Court, in Hurtado v. United States, ${ }^{74}$ implicitly acknowledged that a material witness who has been incarcerated has been deprived of property, namely, the right to use her time and energy as she lawfully sees fit (or to convert her time and energy into money or another type of property). ${ }^{75}$ The Court, however, held that the witness's property had not been taken because the duty to provide evidence at a criminal trial is part of the burden borne by every citizen in exchange for the benefits of having a criminal justice system. ${ }^{76}$

In addition, some courts have recognized that a person has a property right to enter a profession or conduct a business; if a government places such a burden on an individual that practicing the profession or business becomes unreasonably frustrated, then a taking of property may have occurred. ${ }^{77}$ However, the mere desire for compensation does not rise to a property interest, especially if the petitioner entered the profession fully realizing that compensation would not be given for certain types of jobs. ${ }^{78}$

Courts have generally analyzed business assets and contract rights similarly under the mail fraud statute and the Takings Clause.

73. See United States Trust Co. of New York v. New Jersey, 431 U.S. 1, 19 n.16 (1977) ("Contract rights are a form of property and as such may be taken for a public purpose provided that just compensation is paid.”) (citing Contributors to Pa. Hosp. v. Philadelphia, 245 U.S. 20 (1917)); Lynch v. United States, 292 U.S. 571, 579 (1934) ("Valid contracts are property.... Rights against the United States arising out of a contract with it are protected by the Fifth Amendment."); Liggett \& Myers v. United States, 274 U.S. 215, 220 (1927) (holding that the plaintiff's right to make a contract with the United States government had been taken).

74. 410 U.S. 578 (1973).

75. See id. at 588.

76. See id. at 589.

77. See Family Div. Trial Lawyers v. Moultrie, 725 F.2d 695, 705 (D.C. Cir. 1984) ("While we agree ... that some pro bono requirements do not constitute a 'taking,' we think it equally clear that an unreasonable amount of required uncompensated service might so qualify.").

78. See id. at 705; see also Michael Millemann, Mandatory Pro Bono in Civil Cases: A Partial Answer to the Right Question, 49 MD. L. REV. 18 passim (1990) (collecting cases on the relationship between the Takings Clause and required pro bono services by attorneys); Bruce Andrew Green, Note, Court Appointment of Attorneys in Civil Cases: The Constitutionality of Uncompensated Legal Assistance, 81 COLUM. L. REV. 366, 385 (1981):

Although the Supreme Court has not clearly determined that personal services are property for the purposes of the takings clause, there is much support for that conclusion.... The lower courts ... generally consider ... the time, experience, and skill of a professional to be "property" .... 
In both cases, courts have held contract rights, a person's time, a chose in action, and many types of intangible business assets to be property. Likewise, in both cases, courts have refused to find a property interest in the mere expectation of a contract or in the concept of goodwill.

\section{B. Divergent Definitions of Property: Regulatory Property}

In this section, I explore whether the largesse that governments distribute can be considered a property interest, either for the government or for the recipient. Although the concept of government largesse as property has not yet run down completely divergent paths in mail fraud prosecutions and takings claims, the fractured voices sounding in this area of property interpretation indicate that government largesse as property may be one of the most ripe areas for truly divergent approaches to form.

1. Mail and Wire Fraud. The Supreme Court has made it clear that mail fraud only protects the government as a property holder, ${ }^{79}$ for example, in the right to control how its money is spent. ${ }^{80}$ Thus, government largesse, in the form of grants or contracts, might seem to fit the bill $;{ }^{81}$ but what about licenses, charters, franchises, patents, or copyrights? Although many courts recognize that the regulated entity, at least for due process protections, has a property interest in these government imprimaturs, ${ }^{82}$ what type of interest does the regulator hold? Is an unissued driver's license the property of the government? Does the government retain an interest after issuance? Does a fraudulent license application deprive the government of property (perhaps because such a fraud wastes the government's time

79. See McNally v. United States, 483 U.S. 350, 358 (1987) ("[A]ny benefit which the Government derives from the [mail fraud] statute must be limited to the Government's interests as property holder."). If the prosecution wants to avoid having to prove a property interest, the best bet is to rely on 18 U.S.C. $§ 371$, the general statute involving conspiracy to defraud the government, in which the prosecution only needs to prove that the defendant deprived the government of something of value by trickery, deceit, or chicane. See Hammerschmidt v. United States, 265 U.S. 182, 188 (1924).

80. See McNally, 483 U.S. at 360 .

81. Indeed, these cases are usually cut and dried. See supra note 205 and accompanying text.

82. See Dixon v. Love, 431 U.S. 105, 112 (1977) (holding explicitly that suspension of a person's driving license requires satisfaction of the due process requirements of the Fourteenth Amendment, and thus holding implicitly that a person has a property interest in his driver's license); Bell v. Burson, 402 U.S. 535, 539 (1971) (same). 
and money, and thus its property)? Or is there another valid way of examining this puzzle?

The prosecution fares reasonably well in getting the court to recognize government largesse as property when the alleged fraud is perpetrated against a state or local agency, ${ }^{83}$ especially if state law recognizes the intangible interest to be property. ${ }^{84}$ For example, most courts using this approach have held that a franchise is the property of the government.

However, unlike the treatment accorded franchises, ${ }^{86}$ courts have split over whether a license, the information supplied with the license, or the right to issue the license is the property of the state or local government or government agency. Some of the decisions finding a property interest have invoked esoteric property law concepts. ${ }^{87}$

83. One of the more creative attempts by a prosecutor to find property was a case in which the defendant was charged with depriving the zoning commission of its property right to make zoning decisions. See United States v. Goodrich, 687 F. Supp. 567, 572-73 (M.D. Fla. 1988). The court was sympathetic to the prosecutor's attempts. See id. at 573 ("McNally may be a bitter pill for federal law enforcement authorities to swallow in their quest to eradicate public corruption.") But it was not willing to go as far as to assert that "control over property in the abstract was itself a property interest." Id. at 572 .

84. See United States v. Salvatore, 110 F.3d 1131, 1142-43 (5th Cir. 1997) (relying on state law and traditional property law concepts to define property); United States v. Bucuvalas, 970 F.2d 937, 945 (1st Cir. 1992) (looking to state law to interpret the term "property"); Borre v. United States, 940 F.2d 215, 220 (7th Cir. 1991) ("It is logical, therefore, for this court to look to state law in determining whether a cable television franchise constitutes 'property' for purposes of the mail fraud statute.”); United States v. Cleveland, 951 F. Supp. 1249, 1262-63 (E.D. La. 1997) (defining property in reference to both state law and traditional property law); Goodrich, 687 F. Supp. at 572 (stating that property rights are not created by the Constitution or by federal criminal statutes but rather "stem from an independent source such as state law" (quoting Board of Regents v. Roth, 408 U.S. 564, 577 (1972))); United States v. Telink, Inc., 681 F. Supp. 1454, 1456 n.2 (S.D. Cal. 1988) (relying on state law to define property rights).

85. See Borre v. United States, 940 F.2d 215, 220 (7th Cir. 1991) ("Illinois courts have long embraced Blackstone's characterization of a franchise as 'a royal privilege, or branch of the king's prerogative, subsisting in the hands of a subject."' (quoting 11 WILliAm BLACKSTONE, COMMENTARIES at *37)); United States v. Italiano, 701 F. Supp. 205, 207 (M.D. Fla. 1988). As with other types of property, once found, a conviction can rest on the deprivation of the right to control the dispensing of the property. See Borre, 940 F.2d at 222 (holding that even if the village did not lose money in granting the franchise, the mail fraud conviction would be valid if the grant would not have occurred upon disclosure of withheld information, because "loss of control satisfies the requirements of the mail fraud statute"). For a criticism of Borre's property analysis, see generally Michael C. Bennett, Note, Borre v. United States: An Improper Interpretation of Property Rights, 42 DEPAUL L. REV. 1499 (1993).

86. One court even went so far as to distinguish a franchise from a license as a legislative versus a regulatory act. See Borre, 940 F.2d at 221.

87. See, e.g., United States v. Bucuvalas, 970 F.2d 937, 945 (1st Cir. 1992) (comparing the city of Boston's right to control the alienation of liquor licenses to a fee simple determinable with a possibility of reverter); United States v. Turoff, 701 F. Supp. 981, 986 (E.D.N.Y. 1988) 
Others have been influenced by Charles Reich's famous article, The New Property, which argued that the modern view-regarding a license as the property of the licensee, but not the licensor-inverts the historical viewpoint. ${ }^{88}$ Courts relying on this argument have had little difficulty concluding that a licensing body has a property right in controlling who receives its licenses. ${ }^{89}$

Perhaps the most thorough analysis in this regard arises from a series of opinions that dealt with fraudulent efforts to obtain videopoker licenses in Louisiana. Complicating matters in these cases was a state statute that said a video-poker license was a "pure and absolute revocable privilege and not a right, property or otherwise, under the constitution of the United States or of the state of Louisiana." ${ }^{, 90}$ In concluding that the statute did not apply to the state itself, the courts emphasized Reich's notions of property, the substantial income that video-poker parlors generated for the state, ${ }^{91}$ and the state's

(holding that the Taxi and Limousine Commission (TLC) of the City of New York had a property interest in taxicab medallions because the TLC had an action of conversion, with a remedy of either replevin or damages, for medallions obtained under false pretenses).

88. See Charles Reich, The New Property, 73 YALE L.J. 733, 739-45 (1964) (arguing that government largesse has given rise to a unique system of law in which the rights of holders of largesse, and the powers of government over it, have been redefined). See, e.g., United States v. Salvatore, 110 F.3d 1131, 1141 ("As noted by Professor Charles Reich in his seminal article on property rights, a license is an example of government 'largess' that 'is originally public property, comes from the state, and may be withheld completely."') (citations omitted).

89. See, e.g., United States v. Martinez, 905 F.2d 709, 714 (3d Cir. 1990) (holding that a state has a property right in "keep[ing] its medical licenses to itself and [in] bestow[ing] them on persons who had fairly earned them"); United States v. Theodore, No. 87-301-JLT, 1999 WL 997143, at *3 (D. Mass. Oct. 21, 1999) (relying on Martinez to hold that Massachusetts has a property right in controlling the issuance of medical licenses); United States v. Stewart, No. CRIM.-A. 96-583, 1997 WL 688815, at *3-4 (E.D. Pa. Oct. 23, 1997) (relying on Martinez to hold that Pennsylvania has a property right in its control of a "certificate authorizing the company to commence business," i.e., "the right to have the certificate returned and to keep it from those who no longer are fairly entitled to it"). An interesting twist on these cases arises when an officer of the court (an attorney or a police officer) takes a bribe in exchange for dropping charges against a person accused of a crime. If the accused had been found guilty and then had to turn over some license to the state (such as a driver's license for a DUI conviction), does the state have a property interest in the license? Most courts confronted with this issue have found that the states indeed have a property right in the license. See, e.g., Frank v. United States, 914 F.2d 828, 833 (7th Cir. 1990); United States v. Sepulveda, 763 F. Supp. 352, 355-56 (N.D. Ill. 1991).

90. LA. ReV. Stat. AnN. § 27:2 (B) (West Supp. 2000).

91. See United States v. Salvatore, 110 F.3d 1131, 1142 (finding that Louisiana had a property interest in unissued video-poker licenses because the state has "a direct and significant financial stake in its role as issuer of the licenses"). 
continuing involvement in the operation of the video parlors. ${ }^{92}$ Thus, despite an apparent statute to the contrary, Louisiana had a property interest and not a mere regulatory interest in the video-poker licenses. ${ }^{93}$ Furthermore, the state had a property right in controlling who obtained the licenses, so that a person who supplied false information to the licensing board could be convicted of mail or wire fraud. $^{94}$

Does equating a financial interest with a property interest carry much weight? Regarding New York City's interest in issuing taxicab medallions, one court considered such revenue streams to be a vital indicator of a property interest:

The sovereign can buy and sell and manufacture and derive proceeds from those activities only by virtue of the power it possesses as sovereign-namely its police power, its power to tax, etc. It is only through the exercise of those powers that the sovereign obtains the revenues which enable it to function at all and acquire, if it chooses, "property" in the traditional sense. To rob the sovereign of the due exercise of that power by schemes or artifices to defraud, is to rob it of "property" as surely as the good or chattels or money obtained from a private person by similar schemes or artifices. ${ }^{95}$

Interestingly, one of the more unusual and convincing arguments that a state or local government has a property interest in the largesse it distributes came in a majority opinion that actually overturned a

92. See United States v. Cleveland, 951 F. Supp. 1249, 1262 (E.D. La. 1997), aff'd sub nom. United States v. Branston, 182 F.3d 296 (5th Cir. 1999), cert. granted sub nom. Cleveland v. United States, 120 S. Ct. 1416 (2000) (identifying the state's continued control over video-poker licenses as one of the reasons why the licenses were the property of the state). This case was heard by the Supreme Court on October 10, 2000, and addressed the question whether the government's right to issue a license was a property right under the mail fraud statute.

93. For a case in which a plaintiff tried to turn the court's argument on its ear and claim that actions by the state to repeal video-poker licenses represented a Fifth Amendment takings claim or at least a Due Process Clause violation, see Montecino v. Louisiana, 55 F. Supp. 2d 547, 552-53 (E.D. La. 1999), and infra notes 114-16 and accompanying text.

94. See Salvatore, 110 F.3d at 1140 (holding that Louisiana has a property right in its ability to "choose those persons to whom we will transfer [a license]," based, in part, in the recognition that "[i]ncluded in this bundle of property rights are the rights 'to possess, use and dispose' of a particular article" (quoting Loretto v. Teleprompter Manhattan CATV Corp., 458 U.S. 419, 435 (1982))); see also United States v. Bucuvalas, 970 F.2d 937, 945 (1st Cir. 1992) ("In its broadest sense, a 'property' interest resides in the holder of any of the elements comprising the 'bundle of rights' essential to the use or disposition of tangible property or to the exercise or alienation of an intangible right.").

95. United States v. Turoff, 701 F. Supp. 981, 989 (E.D.N.Y. 1988). 
mail fraud conviction. ${ }^{96}$ Judges Lumbard and Winter argued:

By submitting to that application procedure, moreover, the applicant implies that it wants something that only [the agency] has and can give. Without the agency's assent, the permit remains with the agency. The process is tantamount to a contractual transaction where a buyer and seller agree on a mutually satisfactory exchange of consideration. Here, [the agency's] offer to "sell" the permit to [the defendants] was contingent on its first extracting from the "buyers" certain promises affecting how the permit would be used. The bargained-for exchange, in essence, would have been permit for promise. $^{97}$

Thus, when a government body issues a license, it does so in exchange for a license fee and information; as a result, the government has a property right in the fees and the information. If these are not given to the government, it has not received what it expected from the bargain and has thus been defrauded of property. ${ }^{98}$

96. See United States v. Novod, 923 F.2d 970, 973 (2d Cir. 1991). Judges Lumbard and Winter were not willing to overturn prior Second Circuit precedent and were unable to marshal enough interest from their fellow judges to address the issue en banc; nevertheless, the judges felt compelled to present their arguments. See id.

97. Id. at 974 .

98. Some courts have rejected this general argument; however, these cases were decided shortly after the McNally decision, and the jury instructions were often phrased in terms of the government's general right to honest dealings and not in terms of a quid pro quo of license for fee/information. See, e.g., United States v. Kato, 878 F.2d 267, 269 (9th Cir. 1989) ("The government's right to accurate information with respect to its issuance of licenses constitutes an intangible right not encompassed in the mail fraud statute.”); Medical, Inc. v. Angicor Ltd., 677 F. Supp. 1000, 1005 (D. Minn. 1988) (establishing that the FDA does not have a property interest, under the mail fraud statute, in information submitted to the agency to gain an export license). In addition, most might agree that the government does not have a property interest in information that it would like to have, but for which no law actually compels an individual to give. For example, in one interesting series of cases, defendants were convicted of mail fraud for attempting to prevent banks from filing Currency Transaction Reports. The banks were required by law to file these reports to the U.S. Treasury Department for any deposit greater than $\$ 10,000$, largely in order to flag what may be criminal proceeds. However, instead of hiding such activity, these defendants were simply hoping to avoid paying taxes on the deposits. The convictions were based on depriving the IRS of information that it needed in order to effectively pursue its agenda. On appeal, the convictions were overturned, with one court stating: "We refuse to create a new strand in the bundle of property rights which gives the government an ownership interest in information it does not already possess and has not by law compelled an individual to divulge." United States v. Herron, 825 F.2d 50, 58 (5th Cir. 1987); see also United States v. Gimbel, 830 F.2d 621, 626 (7th Cir. 1987) (rejecting the argument that a scheme to withhold information from the Treasury Department amounted to depriving the government of property). On the other hand, a court has found a deprivation of property when the defendant fails to submit correct information to an agency acting purely in a regulatory role. See United States v. Curry, 681 F.2d 406, 411 (5th Cir. 1982) (sustaining the conviction of a 
Some commentators, however, have been critical of this approach, ${ }^{99}$ arguing that a "license simply signifies that the [state] will not hinder or penalize one who pursues this line of work." "100 Much of this approach was developed in an unusually entertaining and readable opinion by Judge Easterbrook that held, at least with regard to a chauffeur's license, the government grant was "a promise not to interfere rather than a sliver of property."101 Thus, a scheme to give cab-license applicants the answers to a required geography test administered by the city of Chicago did not deprive the city of property in the form of a license ${ }^{102}$ or "in the right to control the activities of the employees of the Division of Public Vehicle Operations." 103

Unlike the situation for local or state governments, prosecutors face an uphill battle when trying to convince a court to find that the United States government has a property interest in the licenses it distributes. Most courts have adopted Judge Easterbrook's approach, preferring to distinguish a regulatory interest from a property interest. $^{104}$

political action committee chairman who failed to inform the Election Supervisory Committee that he had embezzled money from his organization, and thus defrauded the Supervisory Committee of the correct financial information that it was due).

99. See, e.g., Donna M. Maus, Comment, License Procurement and the Federal Mail Fraud Statute, 58 U. CHI. L. REV. 1125 (1991) (summarizing and critiquing pre-1991 mail fraud cases involving licenses or permits).

100. Id. at 1149 \& n.136 (quoting Toulabi v. United States, 875 F.2d 122, 125 (7th Cir. 1989)); see also United States v. Mittelstaedt, 31 F.3d 1208, 1220 (2d Cir. 1994) (“"Whether it chooses to use licenses or blanket rules, the government's purpose is to control the private use of property. Thus, a regulatory license is nothing more than a formal embodiment of 'the necessary government approval.'” (quoting United States v. Schwartz, 924 F.2d 410, 417 (2d Cir. 1991) (quoting United States v. Evans, 844 F.2d 36, 37 (2d Cir. 1988)))); United States v. Paccione, 949 F.2d 1183, 1193-95 (2d Cir. 1991) (holding that New York City did not have a property right in unissued dumping permits, although the city did have a property right in permit and dumping fees); McEvoy Travel Bureau, Inc. v. Heritage Travel, Inc., 904 F.2d 786, 792-93 (1st Cir. 1990) (stating, in dicta, that a state regulatory interest is not a property interest); United States v. Murphy, 836 F.2d 248, 253-54 (6th Cir. 1988) (holding that a certificate of registration or a bingo license may be property once issued to an applicant, but that these items were never the property of the state, and thus the state's right to control or object to the issuance of bingo permits is not property protected by section 1341).

101. Toulabi v. United States, 875 F.2d 122, 125-26 (7th Cir. 1989).

102. See id. at 125. The court also noted that Chicago does not put a cap on the number of chauffeur licenses it issues, unlike taxi medallions. See id.

103. Id. The court left open, however, whether "an indictment limited to the contention that Toulabi defrauded Chicago out of the value of its geography test would state an offense" because the jury instructions at Toulabi's trial actually said the opposite. Id.

104. See, e.g., United States v. Kato, 878 F.2d 267, 269 (9th Cir. 1989) (holding that the 
For example, in United States v. F.J. Vollmer, ${ }^{105}$ the government tried to obtain mail fraud convictions for a scheme to purchase assault rifles by filing false certifications to the Bureau of Alcohol, Tobacco and Firearms (BATF). ${ }^{106}$ The prosecution argued that the defendant deprived the BATF of the property "right to control the disposition of . . . firearms." ${ }^{107}$ The court found this approach unpersuasive, noting that the government never owned the rifles and any interest was thus a regulatory interest, not a property right. As a court in a similar case held:

A law prohibiting a particular use of a commodity that the government does not use or possess ordinarily does not create a property right. If it did, many government regulations would create property rights. For example, laws preventing the sale of heroin or the dumping of toxic waste would create government property rights in the drugs or chemicals. Admittedly, the line between regulation and property is difficult to draw with scientific precision, and we do not mean to imply that the government never has a property interest in the limits it imposes on property use. ${ }^{108}$

Federal Aviation Administration's regulatory interest in issuing a pilot's license is not a property right); Semiconductor Energy Lab. Co. v. Samsung Elecs. Co., 4 F. Supp. 2d 473, 476 (E.D. Va. 1998) (explaining that the Patent and Trademark Office does not have a property interest in inchoate patents); Lifschultz Fast Freight, Inc. v. Consolidated Freightways Corp., 805 F. Supp. 1277, 1293 (D.S.C. 1992) (holding that the Interstate Commerce Commission's interest in regulating the trucking industry is not a property interest); Michael Anthony Jewelers, Inc. v. Peacock Jewelry, Inc., 795 F. Supp. 639, 653 (S.D.N.Y. 1992) (stating that the Copyright Office does not have a property interest "in either the matter underlying the copyright or in the copyright registration once issued"); Mylan Lab., Inc. v. Akzo, N.V., 770 F. Supp. 1053, 1072 (D. Md. 1991) (deciding that the Federal Drug Administration does not have a property interest in unissued ANDA (abbreviated new drug application) approvals and that a regulatory interest does not lead to a property interest); Universal Mfg. Co. v. Douglas Press, Inc., No. 89 C 3354, 1991 WL 83156, at*3 (N.D. Ill. May 8, 1991) (stating that the government does not have an intangible property right "to issue legitimate trademarks and copyrights").

105. 1 F.3d 1511 (7th Cir. 1993).

106. See id. at 1513 .

107. Id. at 1521

108. United States v. Evans, 844 F.2d 36, 42 (2d Cir. 1988) (citation omitted); see also United States v. Schwartz, 924 F.2d 410, 417 (2d Cir. 1991) (holding that when the government was falsely induced to issue an arms export license, the government was not defrauded of its property right "to control alienation of the arms" because a regulatory interest is not a property interest). The Evans court was also reluctant to engraft common law rules of property onto international arms sales because "Congress has enacted elaborate laws to limit who may possess or sell weapons," and arms sales are also governed by "foreign and human-rights policies." Evans, 844 F.2d at 42; see also United States v. Elkins, 885 F.2d 775, 781 (11th Cir. 1989) (holding that a defendant who allegedly aided in the illegal export of aircraft to the Libyan 
Surprisingly, the government never argued that the BATF had a property right in the information that is submitted to the agency in return for the grant of the license. ${ }^{109}$

In summary, although inchoate franchises are generally agreed to be the property of the government, the attitude towards other forms of government imprimatur remains uncertain. At the federal level, such intangible interests are rarely found to be government property, but at the state and local level the government is often seen as having a property interest, either in the licenses or in the information submitted by applicants.

2. The Takings Clause. The Supreme Court has long recognized that certain types of government grants, once given, become the property of the holder. For example, in West River Bridge Company $v$. Dix ${ }^{110}$ the Court found that a franchise, although intangible, was property under the Takings Clause. ${ }^{111}$ The Court dismissed an attempt by the government to distinguish between tangible and intangible property and concluded " $[\mathrm{t}]$ he distinction ... has no foundation in reason." $" 112$ This precedent has been used subsequently to find that other types of franchises are the property of the recipient. ${ }^{113}$

military did not deprive the United States of a property right because the right to control foreign policy is not a property right).

109. One of the few winning arguments for the government in this type of case is that the defendant's actions deprived the agency of the right to seek the forfeiture of the illegal weapons. Under 22 U.S.C. $\S 401$ (1994), the government could bring a forfeiture action against a person who was caught illegally exporting weapons. Some courts have held that actions to conceal the true nature of an illegal shipment deprived the government of the right to pursue "a chose in action-a valuable, intangible property right." United States v. Berg, 710 F. Supp. 438, 444-45 (E.D.N.Y. 1989) (citing United States v. Porcelli, 865 F.2d 1352, 1361 (2d Cir. 1989)); see also Evans, 844 F.2d at 41 (using the U.S. government's inability to repossess arms illegally sold to a foreign country as one reason why the government did not have a property right in arms already sold to a foreign country). But see United States v. Bruchhausen, 977 F.2d 464, 467 (9th Cir. 1992) ("The government's potential forfeiture interest is too ethereal to fall within the protections of a statute that "had its origin in the desire to protect individual property rights." (quoting McNally v. United States, 483 U.S. 350, 358-59 n.8 (1987))).

110. 47 U.S. 507 (1848).

111. See id. at 533 .

112. Id. at 534.

113. See Monongahela Navigation Co. v. United States, 148 U.S. 312 (1893) (concerning a franchise to operate locks on river); City of Oakland v. Oakland Raiders, 646 P.2d 835, 839 (Cal. 1982) (en banc) (holding that a city may properly exercise eminent domain over intangible property, including a football franchise); JULIUS L. SACKMAN, 1A NiCHOLS ON EMINENT DOMAIN, $\S \S 2.1[2], 2-8$ to 2-11 (3d ed. 1999) ("Personal property is subject to the exercise of the power of eminent domain. Intangible property, such as choses in action, patent rights, 
On the other hand, licenses have not fared as well. For example, a claimant tried to argue that referenda passed by several Louisiana parishes banning video poker constituted a taking of his property without just compensation. ${ }^{114}$ The claimant argued that, under the mail fraud case law, Louisiana had a property interest in the videopoker licenses, and thus, upon transferring the license, the licensee acquired the property right. ${ }^{115}$ Even though the mail fraud decisions relied on both state and common law to find a property interest for the state, the Montecino court looked no further than the plain wording of the video-poker statute to find that a licensee had, at most, a revocable privilege in the video-poker license. ${ }^{116}$ As a result, the Takings Clause did not apply to the claimant's loss. Although the court's reading of the statute in the takings claim appears to be straightforward, the use of nonstatutory sources to uphold a mail fraud conviction suggests judicial manipulation of standards to fit the needs of the day.

Similarly, at the federal level, licensees have not been able to claim a loss of property when a change in regulations deprives a licensee of a license. For example, the U.S. Claims Court, in Mitchell Arms, Inc. v. United States, ${ }^{117}$ held that an import license granted by the United States to a firearms importer is not a vested property right of the importer; consequently, a change in policy that results in the loss of the license does not rise to the level of a taking. ${ }^{118}$ The court found that the license was not property because the importer could not transfer the license or exclusively import arms (other importers could get similar licenses). ${ }^{119}$ In addition, the license carried no promise of renewal or guarantee against revocation. ${ }^{120}$ Arguably, the court was answering the wrong question: it was not determining whether the import license was property (clearly it was something of great value that allowed the importer to make a living), but whether

\footnotetext{
franchises, charters or any other form of contract, are within the scope of this sovereign authority as fully as land ....") (citations omitted).

114. See Montecino v. Louisiana, 55 F. Supp. 2d 547, 552-53 (E.D. La. 1999).

115. See id.

116. See id. at 552 (stating that a video-poker license is a "pure and absolute revocable privilege and not a right, property or otherwise, under the constitution of the United States or of the state of Louisiana" (quoting LA. REV. STAT. ANN. § 27:2(B) (West 1989))).

117. 26 Cl. Ct. 1 (1992).

118. See id. at 4.

119. See id.

120. See id.
} 
the government essentially had a reversionary interest in the property (i.e., the license) because the weapons covered by the license were potentially politically sensitive items. ${ }^{121}$

3. Government Largesse as Property: Comparing Approaches. In this area of intangible property, courts have consistently regarded certain regulatory approvals as property: franchises and charters. The mail fraud case law holds that these interests are the property of the government, ${ }^{122}$ whereas takings case law holds that they are the property of the recipient. ${ }^{123}$ Thus, as with other tangible items (like land) that the government distributes, the act of transferring the interests neither creates nor destroys property.

A different result arises with regard to licenses, patents, and copyrights. Under a mail fraud analysis, these intangible interests are not the property of the federal government, ${ }^{124}$ but, depending on state law, may be the property of a state or local government. ${ }^{125}$ However, these analyses implicitly acknowledge that the recipient of these grants does hold property. On the other hand, under a typical takings analysis, licenses are the property of the government but not the recipient. $^{126}$

\section{New Definitions of Property}

1. Honest Services. A specialized type of intangible interest that briefly starred in the theater of mail and wire fraud can be generally described as an employer's right to an employee's honest services (i.e., the employee is honest with her employer). ${ }^{127}$ However, this new form of property was effectively killed off by the landmark Supreme

\footnotetext{
121. For example, the license might be considered "taken" if the license had been revoked for an arbitrary and capricious reason or for a reason unrelated to the control of weaponry.

122. See supra notes 83-86 and accompanying text.

123. See supra notes $110-13$ and accompanying text.

124. See supra notes 104-09 and accompanying text.

125. See supra notes 83-103 and accompanying text.

126. See supra Part II.B.2.

127. For a more detailed discussion of this area of mail fraud, see John C. Coffee, Jr., Modern Mail Fraud: The Restoration of the Public/Private Distinction, 35 AM. CRIM. L. Rev. 427, 458 (1998) [hereinafter Coffee, Modern Mail Fraud]; John C. Coffee, Jr., From Tort to Crime: Some Reflections on the Criminalization of Fiduciary Breaches and the Problematic Line Between Law and Ethics, 19 AM. CRIM. L. REV. 117, 128 (1981); Moohr, supra note 14, at 203; and Geraldine Szott Moohr, Mail Fraud Meets Criminal Theory, 67 U. CIN. L. REV. 1, 8-11 (1998).
} 
Court case McNally v. United States. ${ }^{128}$ Congress's subsequent decision not to label "honest services" as property has been generally followed in the courts, ${ }^{129}$ and it is unlikely that a takings claimant would also succeed by advancing "honest services" as a property interest.

Two cases in the early 1940s established that mail fraud law could reach actions that impinged on the employer-employee relationship in the private and public sectors. In the context of the former, a district court held that an employer had a lawful right (and perhaps a property right) to an employee's loyal and honest actions and that a competitor company could commit mail fraud by "tamper[ing] with that relationship for the purpose of causing the employee to breach his duty." "The public's right to the honest services of public officials was born in a Fifth Circuit case concerning the attempt of several New Orleans officials and businessmen to influence the refunding of levee bonds. ${ }^{131}$ It was alleged that in the course of the deal, bribes were paid and lies were told. ${ }^{132}$ Even though the bond refunding scheme resulted in substantial savings to the public, ${ }^{133}$ the court still found fraud, because "[n]o trustee has more sacred duties than a public official and any scheme to obtain an advantage by corrupting such an one [sic] must in the federal law be considered a scheme to defraud." ${ }^{134}$ One reading of this phrase is that all public officials, in return for being elected by the public, owe the public certain "sacred duties." Accordingly, this social contract gives rise to collective property rights held by all citizens.

These early cases were virtually untouched for almost thirty years ${ }^{135}$ until their revival in the early 1970s by the Seventh Circuit Court of Appeals. ${ }^{136}$ A classic private sector example, United States $v$.

128. 483 U.S. 350 (1987).

129. See infra notes 149-52 and accompanying text.

130. United States v. Procter \& Gamble Co., 47 F. Supp. 676, 678 (D. Mass. 1942).

131. See Shushan v. United States, 117 F.2d 110, 115 (5th Cir. 1941).

132. See id. at 114-15.

133. See id. at 119.

134. Id. at 115.

135. One of the rare cases in the interim was United States v. Beckley, 259 F. Supp. 567 (N.D. Ga. 1965), in which the court upheld an indictment charging the defendant with "depriving the telephone company of the honest services of its employees" and "causing the facilities of the telephone company to be used in a manner prohibited by its tariffs." Id. at 571.

136. See McNally v. United States, 483 U.S. 350, 362-64 nn.1-3 (1987) (Stevens, J., dissenting). 
George, ${ }^{137}$ involved a kickback scheme. ${ }^{138}$ Yonan, an employee of Zenith Radio Corporation who was in charge of buying cabinets for the company's new "Circle of Sound" product, received a one-dollarper-cabinet kickback from the Accurate Box Corporation in return for a lucrative cabinet contract with Zenith. ${ }^{139}$ The court noted that Zenith had paid a fair price for the cabinets and, in fact, the profit that Accurate made was within the ten percent allowed by Zenith. Furthermore, the record indicated that Yonan had always insisted on quality and efficiency and had never requested any preferential treatment for Accurate. However, Yonan had agreed to Zenith's policy against accepting gratuities from suppliers twice, in signed documents. ${ }^{140}$ In upholding the conviction, the court clearly tied the employer's deprivation of an owed duty to some financial gain by the employee:

We need not accept the Government's far ranging argument that anytime an agent secretly profits from his agency he has committed criminal fraud. Not every breach of every fiduciary duty works a criminal fraud. But here Yonan's duty was to negotiate the best price possible for Zenith or at least to apprise Zenith that [Accurate] was willing to sell his cabinets for substantially less money. Not only did Yonan secretly earn a profit from his agency, but also he deprived Zenith of material knowledge that [Accurate] would accept less profit. There was a very real and tangible harm to Zenith in losing the discount or losing the opportunity to bargain with a most relevant fact before it. ${ }^{141}$

Similar fact patterns and reasoning were also applied to public officials who used their influence to award contracts to companies in which they either had an interest or from which they received kickbacks. ${ }^{142}$

137. 477 F.2d 508 (7th Cir. 1973).

138. See id. at 510. These types of cases are confusing because essentially identical fact patterns have led to courts identifying two other varieties of property losses: the right to material information critical to a business decision, see infra Part II.C.2; and the right to be able to control how one's money is spent, see infra Part II.C.3.b.

139. See George, 477 F.2d at 510.

140. See id. at 511.

141. Id. at 512-13 (citations omitted).

142. See, e.g., United States v. Bush, 522 F.2d 641, 646-47 (7th Cir. 1975) (finding that a press secretary's use of connections to obtain city advertising contracts for his own company was mail fraud, even if "the city did not lose money on the contract and [the contract] was one of the best in the country"). But see United States v. McNeive, 536 F.2d 1245, 1251-52 (8th Cir. 1976) (holding that St. Louis's chief plumbing inspector's acceptance of a five-dollar tip from a 
The situation changed dramatically, however, when the Supreme Court held, in McNally v. United States, ${ }^{143}$ that the mail and wire fraud statutes did not apply to the "honest services" scenarios. ${ }^{144}$ The Court reached this conclusion by noting that the mail fraud statute was limited to protecting "the Government's interest as property holder," of disclosure and good government for local and state officials" was not a property right. ${ }^{146}$ Any changes in this approach would require a clear statement from Congress. ${ }^{147}$ A later Supreme Court decision

plumbing company did not defraud the city, because the tips were given with permit applications that were issued as part of the inspector's nondiscretionary duties).

143. 483 U.S. 350 (1987). To say that the situation changed dramatically might have seemed, to some judges, to be putting it mildly. See United States v. Goodrich, 687 F. Supp. 567, 573 (M.D. Fla. 1988) ("It risks understatement to observe that McNally came as a surprise to the legal community.").

144. McNally, 483 U.S. at 356.

145. Id. at $358-59$ n.8.

146. Id. at 360; see also United States v. Bucuvalas, 970 F.2d 937, 943 (1st Cir. 1992) ("McNally held that the intangible right to good government is not 'property' ...."). Note that Justice Stevens, who came from the Seventh Circuit, issued a vigorous dissent in McNally, arguing that the mail fraud statute should be broadly interpreted because Congress's purpose in enacting the statute was to "protect the integrity of the United States mails by not allowing them to be used as 'instruments of crime." McNally, 483 U.S. at 365 (Stevens, J., dissenting). More importantly for this general discussion of property, Justice Stevens presaged two approaches that prosecutors could use in order to get around McNally's holding: first, argue that when a person is being paid a salary for loyal services but breaches that duty, the employer is not getting the property he paid for; and second, use principles of agency to argue that an employee is liable to his employer for anything that he gains from violating his duty of loyalty to the employer, and that most kickback schemes would then fulfill the Court's property requirement. See id. at 377 n.10 (Stevens, J., dissenting). A few courts adopted the latter approach, which was known as the constructive trust theory, to sustain mail fraud convictions post-McNally. See, e.g., United States v. Richerson, 833 F.2d 1147, 1157 (5th Cir. 1987); United States v. Fagan, 821 F.2d 1002, 1010-11 n.6 (5th Cir. 1987). However, most courts rejected this theory. See, e.g., United States v. Miller, 997 F.2d 1010, 1020 (2d Cir. 1993); United States v. Walgren, 885 F.2d 1417, 1422-24 (9th Cir. 1989); Callanan v. United States, 881 F.2d 229, 233-34 \& n.2 (6th Cir. 1989). Most courts looked "'beyond the face of an indictment' that used intangible rights language," and tried to find any evidence of monetary or tangible property losses. United States v. Cosentino, 869 F.2d 301, 306 (7th Cir. 1989) (quoting United States v. Bonansinga, 855 F.2d 476, 479-80 (7th Cir. 1988)). Nevertheless, courts often refused to invent new forms of property as a means to uphold a conviction. See, e.g., United States v. Gordon, 836 F.2d 1312, 1314 (11th Cir. 1988) (refusing to hold that citizens have a property right in fair elections, and indicating that the right to fair elections was merely a restatement of the intangible right to honest government disallowed by McNally).

147. See McNally, 483 U.S. at 360. 


\section{extended this holding to employer-employee "honest services" cases. ${ }^{148}$}

Apparently displeased with the Supreme Court's decisions, Congress quickly and clearly responded that the mail and wire fraud statutes also applied to honest services. ${ }^{149}$ However, Congress did not go so far as explicitly to call a public or private employer's right to honest employees "property." Instead, the new statute expanded upon the definition of "a scheme to defraud" by including the phrase "a scheme or artifice to deprive another of the intangible right of honest services." 150 Nevertheless, many courts have subsequently couched the honest services doctrine in terms of employers (public or private $)^{151}$ not getting what they paid for. ${ }^{152}$ Such an approach implies

148. See Carpenter v. United States, 484 U.S. 19, 25 (1987) (noting that a contractual right to honest services is "an interest too ethereal ... to fall within the protection of the mail fraud statute").

149. See National Narcotics Leadership Act of 1988, Pub. L. No. 100-690, § 7603, 102 Stat. 4181, 4508 (codified at 18 U.S.C. $\$ 1346$ (1994)). For critical commentary on the legislative history of section 1346, see United States v. Brumley, 116 F.3d 728, $742-45$ (5th Cir. 1997) (Jolly \& DeMoss, JJ., dissenting); Adam H. Kurland, The Guarantee Clause as a Basis for Federal Prosecutions of State and Local Officials, 62 S. CAL. L. REV. 367, 487-91 (1989); and Moohr, supra note 14 , at $169-70$.

150. 18 U.S.C. § 1346 (1994).

151. See, e.g., Brumley, 116 F.3d at 731-32 (holding that "another" in section 1346 includes "a governmental entity," but not going as far as including citizens of the body politic). However, some courts have held that honest services are owed to the general citizenry as part of the social contract inherent in our government. See United States v. Jain, 93 F.3d 436, 442 (8th Cir. 1996) ("In a democracy, citizens elect public officials to act for the common good. When official action is corrupted by secret bribes or kickbacks, the essence of the political contract is violated.").

152. In the context of public officials, see, for example, Brumley, 116 F.3d at 734-35 (holding that a citizen's rights to honest services "has little relevant meaning beyond a shorthand statement of a duty rooted in state law and owed to the state employer"). But see United States v. Bloom, 149 F.3d 649, 654-57 (7th Cir. 1998) (noting that "violations of state-law fiduciary duties do not turn into mail fraud just because the mails are used in the process"; rather, "[a]n employee deprives his employer of his honest services only if he misuses his position (or the information he obtained in it) for personal gain"). In the context of private sector contracts, the courts have generally been unwilling to label any contract breach as subject to criminal prosecutions. See United States v. Pennington, 168 F.3d 1060, 1065 (8th Cir. 1999) (noting that in the private sector a "mere breach of fiduciary or employee duty may not be sufficient" to be guilty of mail fraud; under section 1346, defendants "must also cause or intend to cause actual harm or injury, and in most business contexts, that means financial or economic harm") (citations omitted); United States v. Cochran, 109 F.3d 660, 667 (10th Cir. 1997) ("[I]t would give us great pause if a right to honest services is violated by every breach of contract or every misstatement made in the course of dealing.") (citations omitted); Jain, 93 F.3d at 442 (holding that a fiduciary's actions must be material to the other party in order to constitute fraud under the honest services doctrine). However, a few private sector honest services cases appear to be justifying criminal prosecutions of nonstatutory ethical violations. See United States v. Gray, 96 F.3d 769, 775 (5th Cir. 1996) (upholding a conviction under section 1346 of basketball coaches 
that honest services can be considered something an employee offers and an employer accepts-in other words, property. Yet, to use this body of post-McNally case law as precedent for the proposition that an employee's honest services were the property of an employer would be to miss the mark; at most, such courts often treat honest services as property, but do not go as far as to use the term itself.

2. Information Necessary to Make a Business Decision. Perhaps at the cutting edge of the property debate, some courts have held that a business or person has a property interest in information that might be useful for making a business decision. As an example, $\mathrm{X}$ is in charge of buying widgets for his employer; Y, a supplier of widgets, approaches $\mathrm{X}$ and tells her that if she chooses his company as the supplier, Y will provide her with five cents for every widget purchased. ${ }^{153}$ Can $\mathrm{X}$ be charged with mail fraud under the theory that she deprived her employer of the information that she was receiving a kickback (and thus, that Y was willing to sell widgets for less)? ${ }^{154}$

Does the presence of a duty, for example, via an employment contract, convert information into property? As might befit a type of property on the outer fringe, courts have split over this question. This doctrinal divide had its origins in the Supreme Court decision, United States v. McNally, ${ }^{155}$ which held that the right to honest government (and, by implication, the honest services of any employee) was not a property right. ${ }^{156}$ Subsequent appellate decisions, in trying to find a

who violated NCAA rules by taking exams for marginally qualified students because the university was denied the opportunity to recruit better-qualified students). For a general discussion of the actions necessary to trigger section 1346, see Coffee, Modern Mail Fraud, supra note 127, at 463-64 (arguing that private fiduciaries must violate a state or independent federal statute; on the other hand, public fiduciaries already know the expectations that the public has for them, and can thus be prosecuted under the federal common law as long as the alleged nondisclosure involves an economic gain or advantage).

153. This fact pattern is based loosely on United States v. Barrett, 505 F.2d 1091, 1104 (7th Cir. 1974):

[T] he person saddled with the responsibility for devoting loyal service to his employer concealed his secret profit from his employer and denied to that employer the right to know that the supplier of the product or service was willing to continue the supply at a discount to which the employer was entitled.

154. These cases are confusing because essentially identical fact patterns have led to courts identifying two other types of property losses. See discussion supra Part II.C.1 (addressing the right, and loss, of an employee's honest services); infra Part II.C.3.b (discussing the right, and loss, of control over how one's money is spent).

155. 483 U.S. 350 (1987); see also discussion supra Part II.C.1 (discussing McNally and the honest services cases).

156. See McNally, 483 U.S. at 358-59. 
way to redefine honest services in terms of property rights, emphasized that contracting parties have an implicit property right in expecting good faith negotiations, ${ }^{157}$ while others have accentuated the monetary value of the information in order to hold that the information was property. ${ }^{158}$ However, other courts felt that such an interpretation was merely a thinly disguised attempt to get around McNally and generally refused to convert a contractual right (implicit or explicit) into a property right, ${ }^{159}$ especially without evidence that the contracting body suffered some type of financial harm. ${ }^{160}$

157. See, e.g., United States v. Briscoe, 65 F.3d 576, 584 (7th Cir. 1995) ("The acceptance of kickbacks by Mr. Briscoe also deprived the Union of the opportunity to negotiate a more favorable economic position.... The Union had a right to know the entirety of the terms by which it was doing business ....") (citations omitted); United States v. Telink, Inc., 681 F. Supp. 1454, 1456-57 (S.D. Cal. 1988) (arriving at this conclusion, because under state law "violations of this right result in civil liability under both contract law and tort law").

158. The Fifth Circuit, for example, noted:

Our circuit has held, as have others, that in an unregulated market economic detriment sufficient to constitute a mail fraud violation can be shown if the employer is denied "economically material information" that "would lead a reasonable employer to change its business conduct." In such a circumstance, the information is considered a tangible property right.

United States v. Matt, 838 F.2d 1356, 1358 (5th Cir. 1988) (quoting United States v. Fagan, 821 F.2d 1002, 1009 (5th Cir. 1987)). Some courts have also held that the government has a property right in the expectation that contracting parties will negotiate in good faith. See, e.g., Telink, 681 F. Supp. at 1457 (noting that under state law "violations of this right result in civil liability under both contract law and tort law").

159. See, e.g., United States v. Slay, 858 F.2d 1310, 1316 (8th Cir. 1988) (differentiating stealing information from withholding information and holding that the latter does not violate the mail fraud statute); United States v. Covino, 837 F.2d 65, 71-72 (2d Cir. 1988) (reversing wire fraud convictions based on a ruling that the defendant had breached a fiduciary duty by withholding information from his employer because such information is not the property of the employer); United States v. Johns, 742 F. Supp. 196, $214-15$ (E.D. Pa. 1990) (concluding "that the right to know material information, like the right to control spending, is too ethereal to constitute a McNally property interest"). An interesting permutation arose in United States $v$. Regan, 713 F. Supp. 629 (S.D.N.Y. 1989). The government tried to argue that the limited partners in a partnership had a property right to receive truthful information about their partnership's capital gains and losses, and that the defendant had deprived the partners of this property. See id. at 631 . The court did not accept this argument and held that while the limited partners may have had a contractual right to receive such truthful information, "this right creates no property interest in the information allegedly withheld from them." Id. at 635-36.

160. See United States v. Mittelstaedt, 31 F.3d 1208, 1217 (2d Cir. 1994) ("[L]ack of information that might have an impact on the decision regarding where government money is spent, without more, is not a tangible harm and therefore does not constitute a deprivation of section 1341 'property."”). 
Courts, on the other hand, have had little difficulty identifying relevant company information as the property of shareholders. ${ }^{161}$ For example, in the Wedtech scandal, the prospectus for a secondary public offering mailed to Wedtech shareholders failed to disclose that one of the Wedtech directors was receiving part of the fee which had been paid for services rendered in connection with the offering. ${ }^{162}$ The court found that the shareholders could have been defrauded of property, reasoning that shares of stock are property and thus have accompanying property interests ${ }^{163}$ including a "right to monitor and to police the behavior of the corporation and its officers." ${ }^{164}$ The court concluded: "Indeed, given the important role that information plays in the valuation of a corporation, the right to complete and accurate information is one of the most essential sticks in the bundle of rights that comprise a stockholder's property interest."165

3. Right to Control. ${ }^{166}$ The right to control the disposition of a physical object has long been recognized as a separate property right that inheres in a physical object. ${ }^{167}$ Thus, it seems logical that the right

161. Often these property rights are determined by state or common law. See United States v. D'Amato, 39 F.3d 1249, 1258 (2d Cir. 1994). The Second Circuit noted that the following types of information are central to the property rights of shareholders:

[I]nformation available to shareholders as provided by the state of incorporation's laws providing access to corporate books and records; (ii) information that if withheld or inaccurate, would result in rendering information that is public materially misleading; and (iii) information that would materially aid shareholders in enforcing management's fiduciary obligations under state law . . .

Id. at 1259 .

162. See United States v. Wallach, 935 F.2d 445, 460 (2d Cir. 1991).

163. See id. at 462 (remanding for a new trial on the issue of whether, in light of the finding that shares of stock are property, there was fraud).

164. Id. at 463 .

165. Id.

166. This section does not cover cases that deal with the right to control the disposition of tangible goods, because the right to choose to whom one transfers one's property is one of the recognized sticks in the bundle of rights. For example, the Seventh Circuit held that a company had been defrauded of property because it "was induce[d] to part with its [property] on the basis of the false premise, implicitly represented to it by [the defendant] and [the subcontractor], that [the defendant] would not receive a portion of that [property]." Ranke v. United States, 873 F.2d 1033, 1040 (7th Cir. 1989). In other words, the company was deprived of the property right to dispose of its property under its own terms. Similarly, the Second Circuit held that an arms manufacturer who would only sell arms if the buyer promised not to violate arms export laws and regulations was deprived of its property right "to define the terms for the sale of its property" when defendants illegally resold the arms to a communist country. United States v. Schwartz, 924 F.2d 410, 420-21 (2d Cir. 1991). But see United States v. Bruchhausen, 977 F.2d 464, 468 n.4 (9th Cir. 1992) (disagreeing explicitly with Schwartz).

167. See United States v. General Motors, 323 U.S. 373, $377-78$ (1945). 
to control an intangible object inheres in an intangible object. Nevertheless, this extra level of abstraction has challenged the imagination of courts.

a. Control over the disposition of information and other intangible goods. Does a business that has gathered information for its own use have the right to exclude others from this information? Imagine that a patient tells a doctor that he might have AIDS because his same-sex partner has been diagnosed with AIDS. Later, a nurse, who had not been treating the patient, hacks into the patient's computer file, discovers the information and reveals it, for a price, to the patient's employer. Has property been taken sufficient to sustain a mail fraud conviction? Whose property has been taken, the patient's or the doctor's? When faced with a similar fact pattern, courts usually conclude that the business (i.e., the doctor) has been deprived of property, because maintaining the confidentiality (i.e., the right to control access) of revealed information is critical to the success of the business. ${ }^{168}$

One court, when confronted by a defendant who had exploited confidential information given to his law firm, reasoned:

[T]he fact that [the law firm] could not commercially exploit the information by trading on it does not mean the confidentiality of the information had no commercial value to the firm. As several partners of the firm testified, maintaining the confidentiality of the information was of commercial value because, by maintaining confidentiality, the firm would protect or enhance the firm's reputation, with the result that it would not lose its clients and perhaps would gain more clients. ${ }^{169}$

Similarly, employees of a collection agency were found guilty of wire fraud when they tricked the telephone company into revealing confidential customer information. ${ }^{170}$

168. Many courts like to have symmetry; that is, the person to whom the misrepresentation was made must also be the person who lost the property. See, e.g., United States v. Walters, 997 F.2d 1219, 1227 (7th Cir. 1993) ("[O]nly a scheme to obtain money or other property from the victim by fraud violates $\S 1341$. A deprivation is a necessary but not a sufficient condition of mail fraud.").

169. United States v. Grossman, 843 F.2d 78, 86 (2d Cir. 1988); see also United States v. O'Hagan, 139 F.3d 641, 651-52 (8th Cir. 1998) (upholding the indictment of a lawyer charged with defrauding his law firm when he used nonpublic information that the client was about to make a tender offer for another company's stock).

170. See United States v. Louderman, 576 F.2d 1383, 1387-88 (9th Cir. 1978) (holding that 
Does the above analysis also apply if the defendant's use of the information causes no economic harm to the victim? The classic case in this category is the Supreme Court's decision in Carpenter v. United States ${ }^{171}$ in which the defendants were charged with using information gathered by the Wall Street Journal to make stock purchases. ${ }^{172}$ In upholding the conviction, the Court first made it clear that intangible property, such as information, was a type of property protected by the mail and wire fraud statutes ${ }^{173}$ and, interestingly, cited a recent takings case for support. ${ }^{174}$ Of course, the problem with ending the analysis there was that the Journal still had the information, and the defendant's use of the information did not financially harm the owner. The Court responded that the Journal had been deprived of one of its most valuable sticks in the "bundle of rights," the right to exclude: "The confidential information was generated from the business, and the business had a right to decide how to use it prior to disclosing it to the public.... [E]xclusivity is an important aspect of confidential business information and most private property for that matter." information fell under the ambit of the mail fraud statute. ${ }^{176}$ Subsequent decisions have applied Carpenter's reasoning against a broad range of distinct defendants, from sex offenders ${ }^{177}$ to doctors, ${ }^{178}$

information which a customer expects a company to keep confidential is the property of the company, and asserting that customer information is the property of the telephone company because unwanted dissemination prevents it from giving customers the service they expect); see also United States v. Richman, 944 F.2d 323, 334 (7th Cir. 1991) (holding that "an insurance company's claim files are not public information but are the private property of the insurance company"); United States v. Cherif, 943 F.2d 692, 698 (7th Cir. 1991) (finding that a bank's customer's confidential information is a bank's property).

171. 484 U.S. 19 (1987).

172. See id. at 23 .

173. See id. at 25 (noting that the "intangible nature [of the publications schedule and contents of the newspaper column] does not make it any less 'property' protected by the mail and wire fraud statutes").

174. See id. at 26 ("Confidential business information has long been recognized as property.” (citing Ruckelshaus v. Monsanto Co., 467 U.S. 986, 1001-04 (1984))).

175. Id. at 26-27.

176. See id. at 28 .

177. See United States v. Diwan, 864 F.2d 715, 719 (11th Cir. 1989) (holding that the defendant, who, for the purpose of sexual gratification, tricked a talent agency into photographing young girls engaging in sexually explicit conduct, deprived the talent agency of property in the form of "proprietary business information-the identities and the addresses of aspiring actresses").

178. See, e.g., United States v. Willis, 737 F. Supp. 269, 273 (S.D.N.Y. 1990) (discussing Carpenter in a case involving a psychiatrist who used information provided by a patient in 
lawyers ${ }^{179}$ securities traders, ${ }^{180}$ and public officials, ${ }^{181}$ each of which has used the proprietary information of another for their own gain. ${ }^{182}$

Courts have also held that the mail fraud statute protects contract bid information. In these cases, an insider leaks design specifications to a contractor so that a perfectly matched bid can be submitted. Even though the company appeared to be getting just what it wanted, courts have held that the company has been deprived of property because the bid information belonged to the company and the insider was only "entitled to use it ... in the manner directed by the information's owner."

A bizarre variation on this fact pattern occurred in United States v. Czubinski ${ }^{184}$ in which the defendant, a contact representative for the IRS, used his access to tax files to look at privileged taxpayer information. ${ }^{185}$ In contravention of explicit IRS regulations, Czubinski peeked at the tax returns of individuals involved in the David Duke presidential campaign, the assistant district attorney who had investigated his father, and a woman whom he had once dated. ${ }^{186}$ Although Czubinski had publicly bragged that he had valuable information on the David Duke campaign, he had never actually made a dossier, nor had he used the information to his own financial benefit. $^{187}$

The court had to determine whether merely looking at information is a deprivation of property. In its analysis, the court agreed that if the defendant had at least made a dossier of the tax records, a reasonable jury could believe that the defendant had

confidence to make a profitable trade on the stock market).

179. See, e.g., United States v. O'Hagan, 139 F.3d 641, 651-52 (8th Cir. 1998) (applying Carpenter in the case of a lawyer who defrauded a client when he used the client's confidential information to buy stock).

180. See United States v. Newman, 664 F.2d 12, 19 (2d Cir. 1981); United States v. Victor Teicher \& Co., 726 F. Supp. 1424, 1433-34 (S.D.N.Y. 1989).

181. See United States v. Keane, 852 F.2d 199, 205 (7th Cir. 1988) (upholding the conviction of a city official charged with buying property based on confidential city plans).

182. But see United States v. Chestman, 903 F.2d 75, 80 (2d Cir. 1990) (holding that mere "family gossip" concerning the sale of a business does not constitute property under 18 U.S.C. $\S$ 1341 (1994)).

183. United States v. Perholtz, 842 F.2d 343, 366 (D.C. Cir. 1988). Other courts appear impressed by the obvious commercial value of the leaked information. See United States v. Belt, 868 F.2d 1208, 1213-14 \& n.5 (11th Cir. 1989).

184. 106 F.3d 1069 (1st Cir. 1997).

185. See id. at 1071.

186. See id. at 1072.

187. See id. 
intended to do more than satisfy his curiosity. ${ }^{188}$ And if this were the case, then the IRS would have been deprived of property because it had fully intended to keep the information for its own use and benefit. ${ }^{189}$ However, because Czubinski was only a "peeping tom," the court decided that the mail and wire fraud statutes did not protect against this use of information. ${ }^{190}$ Thus, although the data was the property of the IRS, the agency did not have a property right to exclude a merely curious trespasser. ${ }^{191}$

The courts have also applied the Carpenter analysis to other types of intangible goods. Again, an actual economic loss is rarely a relevant factor in the court's analysis; rather, the loss is the defrauded party's inability to control the distribution of its goods. ${ }^{192}$ For example, in United States v. Gray, ${ }^{193}$ the Fifth Circuit held that Baylor University had a property right to give basketball scholarships to the best qualified students, and that a coach who took exams for his players defrauded the university of property. ${ }^{194}$ Another court held

188. See id. at 1075-76.

189. See id. at 1075 .

190. See id. Other authority supports the proposition that mail fraud occurs only where the person taking the information desires to do more than satisfy his curiosity. See Letscher v. Swiss Bank Corp., No. 94 CIV. 8277 (LBS), 1996 WL 183019, at *5 (S.D.N.Y. Apr. 16, 1996) (holding that a bank's request and filing of former employee's confidential information without his permission did not constitute an offense under the mail or wire fraud statutes). But see United States v. Cross, 928 F.2d 1030, 1044 (11th Cir. 1991) (holding that a scheme to satisfy personal sexual appetites by tricking child models into posing nude was mail fraud, even though the pictures were not used for personal gain, because the scheme caused financial harm to others); United States v. Diwan, 864 F.2d 715, 719 (11th Cir. 1989) (holding that a defendant who, for sexual gratification, tricked a talent agency into photographing young girls engaging in sexually explicit conduct deprived the girls of property in the form of the photographs and the "likenesses that emanate therefrom").

191. On the other hand, nearly every state recognizes the right to sue someone who, without permission, looks at your mail, peeps in your window, or listens in on a private conversation, even if the sole purpose of the invasion is to satisfy the perpetrator's curiosity. See DAVID A. ELDER, THE LAW OF PRIVACY $\S 2.18$ (1991). An invasion of tax records would seem to fit the same mold; it is, therefore, curious that the court would require proof that the perpetrator envisioned a financial benefit.

192. For example, in United States v. Billmyer, No. CRIM. 94-29-01-JD, 1995 WL 54471 (D.N.H. Feb. 3, 1995), the defendant, a top officer at American Honda, transferred valuable contract rights in the form of Letters of Intent that allowed successful franchises to be established. See id. at *1. The court held that such acts violated the company's conflict of interest policy, and thus deprived Honda of its property right to define the terms of sale of its property. See id. at $* 7 \&$ n.2.

193. 96 F.3d 769 (5th Cir. 1996).

194. See id. at 775. A district court further extended the mail fraud statute's protection to a university's property right in controlling the distribution of athletic scholarships. See United States v. Walters, 711 F. Supp. 1435, 1446 (N.D. Ill. 1989). However, on appeal, the Seventh 
that an employer has a property right in deciding whom to hire, which it phrased as "exclusive control over the persons and type of person with whom it decided to enter employment agreements and contracts." ${ }^{195}$

b. Control over the disposition of money. Almost without exception, courts have held that control over how one's money is spent is a property right protected by the mail and wire fraud statutes. ${ }^{196}$ Perhaps not surprisingly, some of the more interesting cases in this category arose out of bank transactions. For example, in United States v. Lytle, ${ }^{197}$ a loan officer was indicted on charges of mail fraud for intentionally approving loans in violation of the bank's policies. ${ }^{198}$ The court determined that the award of such unauthorized loans, if proven, would constitute a deprivation of the bank's property right to the exclusive use of its monies. ${ }^{199}$ Similarly, convictions of loan applicants who misrepresented their finances to a lending institution have been upheld, even when the court has acknowledged that the eventual recipient of the loan fully intended to repay the loan. Because the bank had the right to loan money under its own financial standards, attempts to subvert that right deprived the bank of

Circuit rejected the district court's holding with little analysis. See United States v. Walters, 997 F.2d 1219, 1226 n.3 (7th Cir. 1993) (dismissing Walters's conviction without discussing the district court's analysis of the university's property rights). The analysis in Gray has also been applied to Ph.D.-granting institutions. See United States v. Frost, 125 F.3d 346, 367 (6th Cir. 1997) (holding that "the decision to award a degree is in part a business decision," and professors who give degrees to inept students or in exchange for bribes hurt the school's reputation).

195. United States v. Granberry, 908 F.2d 278, 279 (8th Cir. 1990). The court also held that a convicted murderer who concealed his conviction on an application to drive school buses could be convicted of mail fraud because he had deprived the school district of its property right to "exclusive control of the distribution of a limited number of school bus driving jobs," and "exclusive control of who it hires to drive its school children to and from school." Id.

196. See, e.g., United States v. Shyres, 898 F.2d 647, 652 (8th Cir. 1990) ("deprivation of the right to control spending can serve as the basis for a mail fraud conviction."); United States v. Rico Indus., 854 F.2d 710, 714 (5th Cir. 1988) (holding that the "right to control [one's] money" is a valid property right) (citation omitted); United States v. Trie, 21 F. Supp. 2d 7, 20 (D.D.C. 1998) (holding that the phrase "deprived the DNC of the right to control how its money is spent" is not mere surplusage in an indictment for mail fraud). But see United States v. Zauber, 857 F.2d 137, 146-47 (3d Cir. 1988) (rejecting, without analysis, the right to control expenditures as a property right under the mail fraud statute).

197. 677 F. Supp. 1370 (N.D. Ill. 1988).

198. See id. at 1373 .

199. See id. at 1384. 
property. ${ }^{200}$ Convictions have also been sustained when a bank made misrepresentations to lure depositors ${ }^{201}$ or when a broker misused his client's funds to make a secret profit for himself. ${ }^{202}$ However, in the latter situation, courts generally uphold a conviction only if the customers were actually deprived of financial gain.

Another type of case also fits this now familiar fact pattern: the supply officer of a company chooses, without the knowledge of his company, a particular supplier because the latter offers him kickbacks. Courts, choosing among three possible types of intangible property, sometimes prefer to characterize this scheme as a deprivation of the right to control money because the company lost the right to decide whether it wanted to deal with a supplier that was paying kickbacks to its supply officer. ${ }^{203}$ Indeed, the Supreme Court, in dicta, also advocated this approach, noting that the prosecution's "honest services" case could have been saved by charging that "the Commonwealth was deprived of control over how its money was spent." ${ }^{204}$ Accordingly, many courts have also used the "control over

200. See United States v. Dinome, 86 F.3d 277, $283-84$ (2d Cir. 1996) ("Under the mail fraud statute, the definition of property includes intangible property interests such as the right to control the use of one's assets. This interest is injured when a person is deprived of information he would consider valuable in deciding how to use his assets.") (emphasis omitted); United States v. Simpson, 950 F.2d 1519, 1523 (10th Cir. 1991) ("A conspiracy to defraud the victim of the use or control of his money is ... within the purview of the wire fraud statute.").

201. See Prasinos v. National Mortgage Bank of Greece, No. 89 C5378, 1990 WL 114713, at *3-4 (N.D. Ill. July 23, 1990) (finding that the plaintiffs had sufficiently alleged an injury to an intangible property interest- "the right of control over their money while it was frozen and the right to good faith contractual relations"-by claiming that the bank had falsely indicated that interest on deposits in the bank would be tax-free and by concealing "the fact that the bank was not legally entitled to accept deposits").

202. See United States v. Ashman, 979 F.2d 469, 478 (7th Cir. 1992). Similarly, a brokerage house was found to have a property right in controlling the risks that its funds are exposed to, and a broker who entered into risky transactions that were against the brokerage's rules was found guilty of mail fraud. See United States v. Catalfo, 64 F.3d 1070, 1077 (7th Cir. 1995).

203. See United States v. Branton, Crim. No. 85-63, 1994 WL 695794, at *3 (E.D. La. 1994) (holding that a company has a property right in the control of its money and in the economic value of conducting its business without kickbacks); United States v. Finley, 705 F. Supp. 1272, 1286-87 (N.D. Ill. 1988) (holding that control over money and "the value of the possibility of receiving a contract at a lower price" constitute property). The other two types of property losses are: (1) the right to material information critical to a business decision, see United States v. Johns, 688 F. Supp. 1017, 1022 (E.D. Pa. 1988) (noting that several courts after the McNally decision have found a property right to material information ancillary to the property right to control expenditures); supra Part II.C.2; and (2) the right to the honest services of an employee, see supra Part II.C.1. It appears that courts apply no logical formula in choosing a property approach.

204. McNally v. United States, 483 U.S. 350, 360 (1987). 
money" approach to sustain convictions of defendants who have used government grants or contracts to line their pockets. ${ }^{205}$

c. The Takings Clause. The Supreme Court has long recognized that the intangible right to control or dispose of a tangible object is a property right. ${ }^{206}$ Although no court has yet explicitly applied this principle, the Supreme Court has recently implicitly applied the "right to control" principle to intangible property in a takings claim. In Phillips v. Washington Legal Foundation, ${ }^{207}$ the Supreme Court addressed the question of "whether interest earned on client funds held in IOLTA accounts" is the private property of the client for purpose of the Takings Clause of the Fifth

205. See United States v. Madeoy, 912 F.2d 1486, $1493-94$ (D.C. Cir. 1990) (holding that a government program has a property right in controlling how its money is spent, and that the FHA has a property right in its "ability to identify and avoid unworthy loan guarantee applications"); United States v. Granberry, 908 F.2d 278, 279-80 (8th Cir. 1990) (holding that a school district has cognizable property under the mail fraud statute that includes "exclusive control of how its money is spent"); United States v. Little, 889 F.2d 1367, 1368 (5th Cir. 1989) (upholding the conviction of a pipe vendor who paid a 5\% kickback to the supervisors who awarded him the contract by reasoning that "[t]he economic value of the knowledge that the contractor would sell for less is sufficient 'property' to implicate section 1341"); United States v. Kerkman, 866 F.2d 877, 880 (6th Cir. 1989) (holding that Michigan had a right-even though it would result in losing money-to enter into a contract in which one party was receiving kickbacks, because the state Department of Transportation was defrauded of its property right to control its money by not receiving all economically relevant information when entering into a contract); United States v. Fischl, 797 F.2d 306, 311 (6th Cir. 1986) (noting that the defendant in the Kerkman transaction "intended to cheat the State's transportation officials out of information to which they were entitled, under the contract, and which would have warranted their terminating the contract at or close to its very inception"); United States v. Schilling, 561 F.2d 659, 662 (6th Cir. 1977) (finding that the defendant had deprived a member of the court of the "right to object to the sale," a property right under the mail fraud statute); United States v. Telink, Inc., 681 F. Supp. 1454, 1456 (S.D. Cal. 1988) (holding that the government has a property right in the control of how its money is spent because "[o]ne's ownership of money means naught unless one has the concomitant right to control that money"); United States v. Biaggi, 675 F. Supp. 790, 801-02 (S.D.N.Y. 1987) (holding that the Department of Defense (DOD) has a property right in controlling how the money is spent in the contracts it awards, and that the DOD is defrauded of this property when "some of that money is being funneled into the coracketeers' pockets instead of being spent on the military appurtenances, such as pontoons, DOD contracted to buy"), aff'd, 909 F.2d 662, 687 (2d Cir. 1990).

206. See, e.g., Hodel v. Irving, 481 U.S. 704, 715 (1987) ("[T]he right to pass on valuable property to one's heirs is itself a valuable right."). But see Andrus v. Allard, 444 U.S. 51, 65-66 (1979) (holding that depriving a person of the right to sell a product, while clearly one of the sticks within the bundle of rights that forms property, is not a taking of property "because the aggregate must be viewed in its entirety"). Andrus was later limited to its facts. See Irving, 481 U.S. at 717 .

207. 524 U.S. 156 (1998). 
Amendment. ${ }^{208}$ At the time, most state laws required attorneys to place "nominal" client funds in an IOLTA account, the interest of which would be used to pay for indigent legal services. ${ }^{209}$ "Nominal" generally meant that the client's funds were so small that if they were placed in a separate interest-bearing checking account, they would not generate net interest for the client because of banking costs. ${ }^{210}$ Relying on state law, the Court held that the interest was the property of the client. ${ }^{211}$

Interestingly, the Court, in finding a property right, was not concerned that if the client put his money in a non-IOLTA interestbearing account the client would not have an economically realizable value. ${ }^{212}$ Instead, the Court was concerned that the IOLTA laws took away the client's right to control the use of the money in the first place, ${ }^{213}$ that is, whether the money could be used (i.e., collect interest) to the benefit of indigent legal services or no one. Indeed, Justice Breyer, in dissent, noted that " $[\mathrm{t}]$ he most that Texas law here could have taken from the client is ... the client's right to keep the client's principal sterile, a right to prevent the principal from being put to productive use by others." ${ }^{214}$ Despite this criticism, the Phillips decision is doctrinally similar to another Court takings case that involved the right to control a worthless piece of tangible property. ${ }^{215}$

The right to control intangible property is a fully accepted principle of property law under the mail fraud statute. In many ways, mail fraud case law has already accepted the application of the "bundle of rights" concept to intangible interests. Although signs indicate that the Supreme Court also finds the right to control the disposition of one's money to be a property right ${ }^{216}$ for purposes of the Takings Clause, the sole indicator in that regard is the dissent's interpretation of the majority opinion in Phillips.

216. Arguably, the Court also considers the right to control the disposition of information to be a property right. See supra Part II.C.3.a.
} 


\section{Taking Stock of Convergence and Divergence}

This Note has presented a broad picture of how two seemingly discrete areas of law treat property. Mail fraud defines what sorts of property, when taken, can send a person to prison; takings law defines what sorts of property, when taken, can lead to compensation from the government. ${ }^{217}$ Given such seemingly disparate goals, one might expect a concept as malleable as property to have evolved into distinct forms in each of these areas of law unless a broader, overarching principle constrained this tendency to diverge. What has this survey discovered towards this end?

In general, for types of intangible interests that have been analyzed in each area of law, convergent evolution has been more of the norm. For example, both areas recognize trade secrets, ${ }^{218}$ intangible business assets and contract rights, ${ }^{219}$ and franchises ${ }^{220}$ to be property interests. Seldom have courts adopted opposing analyses of intangible property. Nevertheless, because of the confusion over whether licenses are the property of the licensor or the licensee (or, in some cases, the property of both or the property of neither), there are signs of a divergent approach in the making. ${ }^{221}$ However, the most interesting feature this broad study of intangible property has discovered is that mail fraud case law has taken a substantial lead in expanding the concept of property. Thus, under mail fraud, information relevant to a business decision has been given property protection, ${ }^{222}$ and the right to control the disposition of intangible property ${ }^{223}$ has been firmly recognized as one of the sticks (and thus property itself) in a property owner's bundle of rights.

How do these conclusions and observations fit in with the two models proposed in the Introduction-the pragmatist's universe and the idealist's universe? Recall that it was postulated that in the former the desire to sustain convictions would tend to expand the concept of property in mail fraud case law, and the desire to economically expand government projects would tend to narrow the meaning of

\footnotetext{
217. See supra Part I.

218. See supra Part II.A.1.

219. See supra Part II.A.3.

220. Compare supra notes 83-86 and accompanying text with supra notes 110-13 and accompanying text.

221. See supra Part II.B.

222. See supra Part II.C.2.

223. See supra Part II.C.3.
} 
property in takings case law. In some ways, the predictions from the pragmatist have come true; most notably, the mail fraud concept of property is significantly broader than that the takings concept of property. And yet, because few specific examples exist in which mail fraud property is in conflict with takings property, the differences in breadth may be more a matter of hysteresis than a philosophical disagreement. In other words, the issues may not yet have arisen in takings case law. The question therefore remains: how should a court analyze a takings claim centered around an intangible interest already analyzed by a mail fraud court?

\section{AN ARGUMENT FOR THE IDEALIST's UNIVERSE}

In this part I argue that two fundamental goals of our judicial system are realized when takings case law and mail fraud case law share a unified conceptualization of property: not only does consistency constrain the executive branch from overly broad prosecution, but it also provides legitimacy for the government's eminent domain policies. As a result, property concepts from one of these areas of law should serve as precedent for the other.

\section{A. Limiting Prosecutorial Discretion}

One reason it is important to have a consistent definition of property in federal law is to impose a limit on prosecutorial discretion. $^{224}$ Under our federal system, prosecutors have been granted broad discretion to decide whether to bring charges against a suspect. ${ }^{225}$ As one commentator noted:

224. Hypothetically, a consistent definition also ensures that a person is aware of what actions are considered criminal. However, with certain highly flexible criminal statutes (such as mail fraud), this fiction becomes even more suspect. For example, under the mail fraud act, what constitutes property? Due process property; Takings Clause property; criminal property? It is naïve to presume that an individual can know the law when no consistent definition of property is apparent within the federal system.

225. See United States v. Armstrong, 517 U.S. 456, 464 (1996) ("The Attorney General and United States Attorneys retain 'broad discretion' to enforce the Nation's criminal laws." (quoting United States v. Goodwin, 457 U.S. 368, 380 n.11 (1982))). The discretion arises from the duty to help the President "discharge his constitutional responsibility to "take Care that the Laws be faithfully executed." Id. (quoting U.S. CONST. art. II, § 3). "As a result, '[t]he presumption of regularity supports' their prosecutorial decisions and, 'in the absence of clear evidence to the contrary, courts presume that they have properly discharged their official duties.”' Id. (quoting United States v. Chemical Found., Inc., 272 U.S. 1, 14-15 (1926)). 
Discretion is an unavoidable characteristic of our criminal justice system. Legislatures generally enact broad criminal statutes capable of nondiscriminatory application. It then falls to the police and prosecution to identify and select a manageable number of cases to prosecute. Courts acknowledge and accept prosecutorial discretion as a necessary part of the criminal process.... Decisions concerning prosecution are further complicated by changing societal circumstances and local needs. Therefore, courts cannot demand that the government exercise discretion according to fixed, mechanistic formulas. ${ }^{226}$

As a result, judges have been given few constitutional justifications for overturning a conviction because of an improper decision to prosecute. ${ }^{227}$

One method employed by the judiciary to limit the discretion of prosecutors relies upon the standard canons of statutory construction. For example, a judge can hold that a statute, either facially or as applied to a defendant, is void for vagueness. ${ }^{228}$ However, this option is rarely used. ${ }^{229}$ More commonly, judges will hold that a statute has several reasonable interpretations and then, using the rule of lenity, apply one of the narrow standards. ${ }^{230}$ In either case, a consistent application of the term "property" in the federal system gives a judge guidance and precedent for labeling a person's actions as criminal.

\section{B. Legitimizing the Takings Clause}

Perhaps the most important rationale for matching the concept of property under the Takings Clause and the federal criminal law is that it assures us, as citizens, that the scales of justice are balanced. Not only does a criminal conviction place a severe stigma on a person,

226. Anne Bowen Poulin, Prosecutorial Discretion and Selective Prosecution: Enforcing Protection After United States v. Armstrong, 34 AM. CRIM. L. REV. 1071, 1079-81 (1997).

227. One of the few ways to invalidate a prosecutor's decision is to demonstrate that it was based on "'an unjustifiable standard such as race, religion, or other arbitrary classifications." Id. (quoting Oyler v. Boles, 368 U.S. 448, 456 (1962)).

228. The void for vagueness doctrine "ensures that citizens will have fair warning of consequences before they act and also seeks to contain prosecutorial discretion within defined boundaries." George D. Brown, Should Federalism Shield Corruption?_Mail Fraud, State Law and Post-Lopez Analysis, 82 CORNell L. REV. 225, 283-84 (1997).

229. See Philip P. Frickey, Interpretation on the Borderline: Constitution, Canons, Direct Democracy, 1996 AnN. SuRV. AM. L. 477, 501 (1996).

230. The rule of lenity places limitations upon prosecutorial discretion and "provides a judicial justification for trimming expansive statutory language which might provide tempting opportunities to overzealous or improperly motivated prosecutors." Id. 
it also permits the state to deprive the convicted of liberty and property. The state sets standards for determining which actions lead to a person bearing these burdens, so that the broader citizenry can peacefully pursue their lives. As such, the state should justify these standards.

On the other side of the equation, the Takings Clause ensures that the costs of a state action enjoyed by many will not be disproportionately borne on the shoulders of a few. When the state denies compensation, it determines that the burden is not beyond what is expected of individuals in return for the broader right to peacefully pursue their lives. Correspondingly, the state also needs to justify these standards.

What better way to legitimize both standards than to make them equivalent? In essence, actions under federal criminal laws, such as mail fraud, and actions under eminent domain deprive someone of property; why shouldn't the government recognize the same concept of property in both cases? A quid pro quo approach ensures that attempts to expand the reach of federal criminal law will be constrained by the state's willingness to compensate, and that the expansion of the state will be constrained by its willingness to convict.

\section{The CONVERGENCE OF INTANGIBLE PROPERTY}

Returning to the types of intangible property discussed earlier, ${ }^{231}$ how should convergence be effected (especially in the areas in which mail fraud case law is substantially ahead of the curve in defining property)?

In the area of licenses, mail fraud and takings laws need to craft a consistent portrait of the licensing process. I recommend that government agencies not have a property interest in inchoate licenses, but rather have a property interest in the information, promises, and fees that applicants submit in order to get licensing approval. Conversely, a license, once issued, becomes the property of the licensee, subject, of course, to the reasonable expectation that government may have to modify the scope of the property rights in a nonarbitrary and noncapricious manner. This view of the licensing process recognizes the value of the submitted information, promises, and fees to the government and the value of the license to the livelihood of the licensee. Furthermore, this view would protect the

231. See supra Part II.D. 
government from fraudulent misrepresentations, protect the licensee from irresponsible government, and present a rational quid pro quo.

We are confronted with a different situation in the case of information relevant to a business decision. Unlike the mail fraud case law, courts have not yet addressed whether such information is property under a takings analysis. However, one can imagine a takings case in which the claimant argued that the government took away from him "'economically material information' that 'would lead a reasonable employer to change its business conduct,", 232 perhaps by a change in regulations.

Under my convergence theory of property, the government should either compensate the claimant or stop using the approach to convict mail fraud defendants. The unsettled nature of the case law for this type of information cautions against making a pronouncement in either direction. Nevertheless, when confronted with a mail fraud case in which the prosecutor urges this type of information to be property, judges should consider whether they would be willing to award compensation for a similar type of takings claim.

Consistency of concepts should be one of the fundamental goals of our judicial system. Not only does consistency constrain the executive branch from bringing overly broad criminal prosecutions, but it also provides legitimacy for the government's eminent domain policies. Accordingly, property concepts in federal criminal law should mirror property concepts in takings case law.

232. United States v. Matt, 838 F.2d 1356, 1358 (5th Cir. 1988) (quoting United States v. Fagan, 821 F.2d 1002, 1009 (5th Cir. 1987)). 